\title{
Temperature Distortion Generator for Turboshaft Engine Testing
}

\author{
NASA-TM- 83748 \\ 19850007349
}

Gary A. Klann

Propulsion Laboratory

AVSCOM Research and Technology Laboratories

Lewis Research Center

Cleveland, Ohio

and

Richard L. Barth and Thomas J. Biesiadny

Lewis Research Center

Cleveland, Ohio

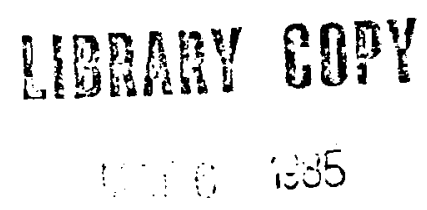

LANGLEY FESEARCH CENTEP.

December 1984

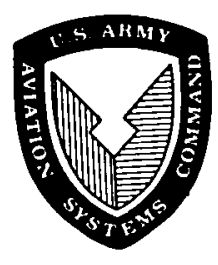


TEMPERATURE DISTORTION GENERATOR FOR TURBOSHAFT ENGINE TESTING*

\author{
Gary A. Klann \\ Propulsion Laboratory \\ AVSCOM Research and Technology Laboratories \\ Lewis Research Center \\ Cleveland, Ohio 44135 \\ and \\ Richard L. Barth and Thomas J. Biesiadny \\ National Aeronautics and Space Administration \\ Lewis Research Center \\ Cleveland, Ohio 44135
}

\title{
SUMMARY
}

The procedures and unique hardware used to conduct an experimental investigation into the response of a small-turboshaft-engine compression system to various hot gas ingestion patterns are presented. The temperature distortion generator described herein uses gaseous hydrogen to create both steady-state and time-variant, or transient, temperature distortion at the engine inlet. The range of transient temperature ramps produced by the distortion generator during the engine tests was from less than $111 \mathrm{deg} \mathrm{K} / \mathrm{sec}$ ( $200 \mathrm{deg} \mathrm{R} / \mathrm{sec}$ ) to above $611 \mathrm{deg} \mathrm{K} / \mathrm{sec}(1100 \mathrm{deg} \mathrm{R} / \mathrm{sec})$; instantaneous temperatures to $422 \mathrm{deg} \mathrm{K}$ (760 deg R) above ambient were generated. The distortion generator was used to document the maximum in let temperatures and temperature rise rates that the compression system could tolerate before the onset of stall for various circumferential distortions as well as the compressor system response during stall.

\section{INTRODUCTION}

When rotary-wing aircraft hover near the ground, the hot engine exhaust gas can be recirculated into the engine inlet by the rotor downwash (fig. 1). This reduces the power avallable (refs. 1 to 3 ) and the compression system stall margin (refs. 1 and 3). This effect is similar to that encountered when gun or rocket exhaust gases are ingested. Although the reingestion phenomenon is reasonably well understood, the confident prediction of reingestion levels for any arbitrary helicopter/engine design and their effect on engine performance requires a comprehensive set of design data not currently avallable (ref. 3). Typically, model and flight tests have been conducted to measure the magnitude and effects of this ingestion (ref. 3 ).

The research work reported herein and in reference 4 is one step toward a better understanding of the response of a typical small turboshaft engine to hot-gas ingestion in the controlled environment of a ground-level test facility. A temperature distortion device, consisting of a gaseous hydrogen burner with individually controlled $45^{\circ}$ sectors, was installed upstream of an engine

* Similar to material presented at the 1984 SAE Aerospace Congress and Exposition, Long Beach, California, October 15-18, 1984. 
inlet to create various steady-state and transient temperature distortion patterns. The engine was instrumented with steady-state and high-response probes to record engine inlet conditions and engine response. The range of the transient temperature ramps was from less than $111 \mathrm{deg} \mathrm{K} / \mathrm{sec}(200 \mathrm{deg} \mathrm{R} / \mathrm{sec}$ ) to above $611 \mathrm{deg} \mathrm{K} / \mathrm{sec}(1100 \mathrm{deg} \mathrm{R} / \mathrm{sec})$; instantaneous temperatures to $422 \mathrm{deg} \mathrm{K}$ (760 deg R) above ambient were generated, as determined from the high-response temperature data at the engine inlet. Stall and no-stall conditions were produced at various engine power settings.

\section{APPARATUS}

\section{Engine}

The engine (fig. 2) that was used with the temperature distortion generator was a front-drive, turboshaft engine consisting of an integral particle separator; a single-spool gas generator section consisting of a five-stage axial-flow, single-stage centrifugal-flow compressor, a throughflow annular combustor, and a two-stage axial-flow gas generator turbine; and a free twostage axial-flow power turbine.

\section{Instrumentation}

The instrument station locations and the distribution of high-response instrumentation at the engine inlet are shown in figure 3 . The engine compression system was also heavily instrumented with high-response and stready-state pressure instrumentation to record the response of the compressor to iniet temperature distortion. The thermocouple calibration procedure is described in the appendix.

\section{Test Facility}

The temperature distortion generator and engine were run in a ground-level test facility. The facility has an atmospheric inlet and atmospheric, as well as altitude, exhaust capability (fig. 4). The hardware required to support the testing included an eddy-current dynamometer rated at $1640 \mathrm{~kW}(2200 \mathrm{hp})$, a gearbox with a 3.743 gear ratio, an inlet bellmouth, an airflow measurement spool piece, and a device to measure airflow dumped overboard through the scavenge blower on the engine.

\section{Temperature Distortion Generator}

The temperature distortion generator can create both steady-state and time-variant, or transient, temperature distortion at the engine inlet by. using gaseous hydrogen. It is an adaptation of a device described in reference 5 . The burner (fig. 5) consists of eight individualiy controlled sectors, with three swirl cup combustors (fig. 6) per sector. Not shown are stainless steel straps that were installed between the cups in each sector to aid flame propagation.

The hydrogen system supplied gaseous hydrogen fuel to the eight-zone burner. The system schematic is shown in figure 7 . Since each zone could be controlled individually, the burner could be operated in many combinations of 
single and multiple zones. For safety, the engine was required to be running at or above idle speed for distortion burner operation. The system was operated from the control room at cabinet 14 , which is described in figure 8 .

The gaseous hydrogen was supplied from portable K-bottles connected to a three-bottle manifold located at the traller pad (fig. $7(a)$ ). If more gaseous hydrogen was needed than could be supplied by the K-bottles, the system could also be supplied by a $1982-\mathrm{m}^{3}, 16.5-\mathrm{mPa}\left(70000-\mathrm{ft}^{3}, 2400-\mathrm{psig}\right)$ capacity tube trafler by changing the hardware at the bottle manifold.

The gaseous hydrogen supply was filtered and the pressure was regulated near the storage area. The gaseous hydrogen was filtered to 5 micrometers absolute. A differential pressure switch (FH106) was used to monitor the condition of the filter and would initiate an annunciator alarm at $138 \mathrm{kPa}$ (20 psid). Two dual-diaphragm pressure regulators (FH108 and FH109) reduced the K-bottle supply pressure to 2100 and $965 \mathrm{kPa}(300$ and $140 \mathrm{psig}$ ), respectively, and maintained the system 1 ine pressure at $965 \mathrm{kPa}$ (140 psig). The gaseous hydrogen was delivered to building shutoff valve FHI18 (located outside the cell wall) by $19 \times 1.7 \mathrm{~mm}(3 / 4 \times 0.065 \mathrm{in.})$ stainless steel tubing. The gaseous hydrogen flow rate to the test cell was measured by venturi FHI16, which also limited the flow to a maximum of $0.224 \mathrm{~m}^{3} / \mathrm{sec}\left(475 \mathrm{ft}^{3} / \mathrm{sec}\right)$.

Inside the test cell (fig. $7(b)$ ), the gaseous hydrogen supply was controlled by the main burner flow control and shutoff valves (FHII9 and FH122) and the pilot flow control and shutoff valves (FHI23 and FH124), which were installed in parallel.

Gaseous hydrogen was delivered to each of the eight zones through 6.4-mm (1/4-in.) stainless steel tubing and the eight remotely operated supply valves (FH141 to FH148). A spark plug in each zone was the ignition source. Individual temperatures were controlled by the eight remotely operated throttling values (FH125 to $\mathrm{FH} 132$ ). A thermocouple in each zone provided remote temperature indication. Once a zone was 1it, an annunciator alarm would sound if the temperature fell below $478 \mathrm{~K}\left(860^{\circ} \mathrm{R}\right)$ (indicating a flameout); in addition, the gaseous hydrogen supply valve (or valves) would close and the zone purge valve (or valves) would open.

The system can create transient temperature ramp rates to $1666 \mathrm{deg} \mathrm{K} / \mathrm{sec}$ $(3000 \mathrm{deg} \mathrm{R} / \mathrm{sec}$ ) in single- or multizone patterns. Less intense ramps were run during the actual engine tests because the engine always stalled before the system capability was reached. During transient operation of the system, a steady-state pattern was first set up through the main burner flow control value by using the zone supply and throttle valves. The flow was then pulsed by quickly opening and closing the pllot valve to ramp the preset temperature pattern up and down, a "spike." The magnitude of the spike was gradually increased by presetting the flow control valve at increasingly open positions until onset of engine stall.

Temperature profiles at the engine inlet were measured by five-point cantilevered thermocouple rakes ( $\mathrm{fig} .3$ ), which were located two duct diameters downstream of the burner. These temperatures were observed in the control room on a 50-channel bar graph display.

The entire hydrogen system was purged once before each test run and once after each test run with gaseous nitrogen. A hand-operated valve (N212), 
located near the trafler pad, supplied gaseous nitrogen to the system at 1 MPa (150 psig). The gaseous hydrogen supply line was purged through the zone throttling valves (FHI25 to FH132) and discharged through the cell vent valve (FH166) to the roof vent. Inside the cell, the eight gaseous hydrogen zone supply lines and the eight burner zones were purged through valves N231 to N238. The purged gas was then vented through the engine and out the facility exhaust system. Since the electric actuators of the throttle, supply, and purge valves were not rated for operation in hazardous locations, these actuators were enclosed in a gaseous nitrogen atmosphere.

The hydrogen system setup and shutdown, operation, and safety control logic was implemented by using a process controller (PC). The PC took a permissive role during setup and shutdown of the system to ensure that these steps were taken in a safe order. The PC could also aid in troubleshooting because it could quickly pinpoint problems. During operation of the system, each of the eight zones was controlled by a separate set of logic although any number of zones could operate together in the multizone mode. The diagram in figure 9 describes the zone operation.

A systems hazards analysis indicated that three recovery action sequences, or system shutdowns (table I), should be controlled by the PC. Temperature and pressure sensors were used to monitor critical system parameters. The PC implemented the safety control.logic on the basis of the severity of a sensed out-of-limit condition. Another circuit was used to sense out-of-limit engine and facility parameters and to initiate emergency shutdown procedures independently of the PC; this included placing the gaseous hydrogen burner in the power-off, fail-safe position.

Table II contains checklists for gaseous hydrogen bottle connection, burner operation, and system purge and shutdown. Table III describes in detall the hardware used in the system.

\section{CONCLUDING REMARKS}

In summary, the temperature distortion effects of hot-gas ingestion in small turboshaft engines can be simulated by using the gaseous hydrogen temperature distortion generator. It is a versatile device that can be used to simulate a large variety of steady-state and transient temperature distortion patterns. The system can be duplicated by using the hardware and procedural information provided. 


\section{APPENDIX - CALIBRATION OF THERMOCOUPLE PROBE USED FOR}

\section{TESTS OF SMALL TURBOSHAFT ENGINES}

This appendix briefly describes the calibration of a Chrome1-Alume 1 thermocouple probe used during tests of small turboshaft engines. The purpose of this writeup is to acquaint others with a general thermocouple calibration procedure and also to present specific time-constant data for a certain thermocouple probe. A schematic view of the probe is included in this appendix as figure 10.

The calibration, performed in a ground-level test cell, consisted of acquiring the necessary data to calculate the time constant $\tau_{0}$ for the Chrome 1-Alumel thermocouple. The time constant of a system is usually defined as the time required for the system to reach 63.2 percent of its steady-state value (ref. 6). The value of 63.2 percent comes from the fact that many timevarying functions can be represented by the exponential relation

$$
T=\left(T_{1}-T_{0}\right) e^{-t / \tau}+T_{0}
$$

where $t$ is the time variable, $T_{1}$ is an initial excited state, $\tau$ is a constant, and $T_{0}$ refers to the steady-state value of $T$ (when $t$ approaches $\infty)$. When $t=\tau$, equation (1) becomes

$$
T=\left(T_{1}-T_{0}\right) e^{-1}+T_{0}=0.368\left(T_{1}-T_{0}\right)+T_{0}
$$

In other words, when $t=\tau$, the difference between $T$ and $T_{j}$ is 63.2 percent of the difference between the initial and the steady-state values of $T$. This situation is displayed in figure 11 .

The procedure used to obtain the time constant of the probe in this investigation was quite simple. The experimental setup is shown in figure 12 (a modification of a figure from ref. 7). Here the probe, mounted to receive flow from a nozzle, was heated to an initial excited state by a hot-air blower. While being heated, the thermocouple was protected from the ambient conditions of the nozzle flow by a simple shield. Once the thermocouple achieved equilibrium in the excited state, the shield and the hot-air source were pneumatically removed at the same instant, and the thermocouple was exposed to the air flowing from the nozzle.

The response of the excited thermocouple to the nozzle flow is recorded on both a digital voltmeter and a strip-chart recorder. The voltmeter readings are necessary to calibrate the strip chart. An example strip-chart recording is shown in figure 13 (from ref. 8). The time constant of the probe $\tau$ is measured as the recorded time required to reach $0.368 \times\left(T_{1}-T_{0}\right)$ on the temperature scale. The value of $\tau$ will vary with respect to various nozzle flow conditions and initial thermocouple temperatures. Reference 2 suggests using the following expression to calculate a reference time constant $\tau_{0}$ :

$$
\tau_{0} \approx \tau \sqrt{\frac{M p}{P_{0}}}\left(\frac{T_{1}}{T_{0}}\right)^{0.18}
$$


where

T measured time constant, sec

M stream Mach number

p stream static pressure, psia

P0 reference static pressure, $0.704 \mathrm{kPa}$ (14.696 psia)

$T_{1}$ probe indicated temperature, ${ }^{\circ} \mathrm{R}$

$\mathrm{T}_{0}$ reference temperature, $555 \mathrm{~K}\left(999^{\circ} \mathrm{R}\right)$

This time constant should remain a constant for a particular probe over a wide range of flow and initial temperature conditions.

The time constant values calculated for the T700 probe are displayed in table IV, and again, figure 10 shows the probe design. The time constants for the probe were measured and then averaged from three runs performed over each of six Mach number conditions. Within each three-run set the measured time constants showed very close agreement. Between the sets the time constant values increased as expected. With each decrease in flow Mach number. Apparently, the reference time constant equation became invalid for stream Mach numbers of 0.10 or less, but a fairly steady value of $\tau_{0}$ was found over the Mach number range 0.15 to 0.40 . This value could possibiy remain constant beyond the 0.40 Mach number condition, but the calibration was based on expected flow conditions in the engine tests, which did not exceed Mach 0.40 . 


\section{REFERENCES}

1. Sheridan, P.F.; and Wiesner, W.: Aerodynamics of Helicopter Flight Near the Ground. AHS Paper 77.33-04, 1977.

2. Turczemick, Bohdan: Exhaust Gas Reingestion Measurements. AHS Paper HPS-23, 1979.

3. Jackson, M.E.; and House, R.L.: Exhaust Gas Reingestion During Hover InGround-Effect. Proceedings, American Helicopter Society, 37th Annual Forum, New Orleans, May 1981, pp. 378-385.

4. Biesiadny, Thomas J.; Klann, Gary A.; and Little, Jeffery K.: Response of a Sma 11-Turboshaft-Engine Compression System to Inlet Temperature Distortion. NASA TM-83765. (ATso AVSCOM-TR-84-C-13.)

5. Pawlik, E.V.; and Jones, R.E.: Experimental Evaluation of Swirl-Can Elements for Propane-Fuel Combustor. NASA Memo 5-15-59E, 1959.

6. Holman, J.P.: Experimental Methods for Engineers. McGraw-H111, 1978, Pp. 25.

7. Glawe, George E.; Holanda, Raymond; and Krause, Lloyd N.: Recovery and Radiation Corrections and Time Constants of Several Sizes of Shielded and Unshielded Thermocouple Probes for Measuring Gas Temperature. NASA TP-1099, 1979.

8. Scadron, Marvin D.; and Warshawsky, Isidore: Experimental Determination of Time Constants and Nusselt Numbers for Bare-Wire Thermocouples in HighVelocity Air Streams and Analytic Approximation of Conduction and Radiation Errors. NASA TN-2599, 1952. 
TABLE I. - GASEOUS HYDROGEN SYSTEM SHUTDOWNS

\begin{tabular}{|c|c|c|}
\hline $\begin{array}{l}\text { Shutdown } \\
\text { sequence }\end{array}$ & Cause & Results \\
\hline 1 & $\begin{array}{l}\text { Manual pushbutton } \\
\text { Line pressure switches ( } 1112 \\
\text { (FII3) out of limits }\end{array}$ & $\begin{array}{l}\text { Annuclator alarm } \\
\text { Traller supply valve closes } \\
\text { Bullding supply valve (FHll8) closes } \\
\text { Cell line vent valve (FHl66) opens, } \\
\text { venting line in cell to zero } \\
\text { All zone supply valves close } \\
\text { Zones are automatically purged and } \\
\text { then shut off manually }\end{array}$ \\
\hline 2 & $\begin{array}{l}\text { Engine dropping below idle } \\
\text { Manual pushbutton or key } \\
\text { switch } \\
\text { Sequence } 1 \text { shutdown } \\
\text { Gaseous nitrogen supply } \\
\text { pressure low (N208 and } \\
\text { N220) } \\
\text { Low flow of gaseous nitrogen } \\
\text { purge for electric valves } \\
\text { in cell (N228) }\end{array}$ & $\begin{array}{l}\text { The same as for sequence } 1 \text { except } \\
\text { that the trailer valve does not } \\
\text { close }\end{array}$ \\
\hline 3 & $\begin{array}{l}\text { Zone temperature dropping } \\
\text { below limit }\end{array}$ & $\begin{array}{l}\text { Annunciator alarm } \\
\text { Zone gaseous hydrogen supply valve } \\
\text { closes } \\
\text { zone purge is started and must be } \\
\text { manualiy turned off }\end{array}$ \\
\hline
\end{tabular}


TABLE II. - CHECKLISTS

T-7OD ENGINE PROGFAN

SIGA CFF ................ GROUP NO. 7

GH2 BOTTLE CONNECTION

.................

* NOTE * E.S. AND SI MUST BE SATISFIEC ICO2, HYD. OIL, EXH. FAN, V4 2 OPEN, LOUVERS OPEN)

-.. obiain key for purge valve nzli (ecrl key box)

... LOCATE 2 MEN at the tRailer with WalKIE talKies. *NOTE \#ALKIE TALKIES MUST REMAIN 25 FT FROM THE
IRAILER.

-.. block off the area nith the apFropriate barricades ANO STROBE LIGLTS.

-... check main gn 2 SUPply Valve at bottle farm is open.

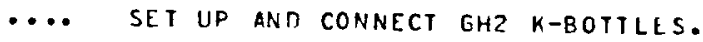

-... unlock purge hand valve n212.

... ofen high pressure gnz supply tanc valve nzcz.

-... CHECK PR. REG. N2O3 SET AT 60 +SIG.

... CHECK THAT PR. REg. N2OS SET AT 100 FSIE.

-... CHECK THAT PR. REg. N213 SET AI 350 PSIG.

-... CHECK THAT LOACERS N214 ANO N217, FOR PR. REG. FH108 AND FHICQ, ARE BACKED CFF TO ZEFC ON GAGES N215 ANE N218.

-... open purge hanc valve nz12.

-... open gage hano valve fH102 and check purge press. ABOUT ICD PSI ON GAGE FHID3.

... open the main manifold hand valve fhiol.

-.. open the ghz manifolo hand valie lseg fcr purging.

-.. CHECK ghz PANEL POWER KEY SWIT.Ch IS CN.

-... OPEn trailer remote shutoff VAlVe ane PURGe 30 secs. THE SHITCH MUST BE HELD IN SINCE THERE IS NO LINE PRESSURE.

-... close the ghz manifold hand valve used for purgiag.

-... OPEN BUfNer PILOT Shutoff VALVE FH124

-... OPEn blCG. GH? Shutoff VALVE fH.118.

... check CELl vent VAlve fH166 is open.

-... open main ghz flow control valve fhilg full open.

-... OPEN GHz PILOT flow CONTROL VALVE fH123 to 30 PSig.

... OPEN HIGH FLOW SHUTOFF VALVE FH 122 .

-... open system vent valve fH111.

.... LOAD PR. PEG FH108 TO 325 PSIG HITH LOADEF N214.

-... LOAT PR. REg. FHIOg TO 140 PSIC WITH LOADER N217.

-... PURGE FOR 2 MIN. 
TABLE II. - Continued

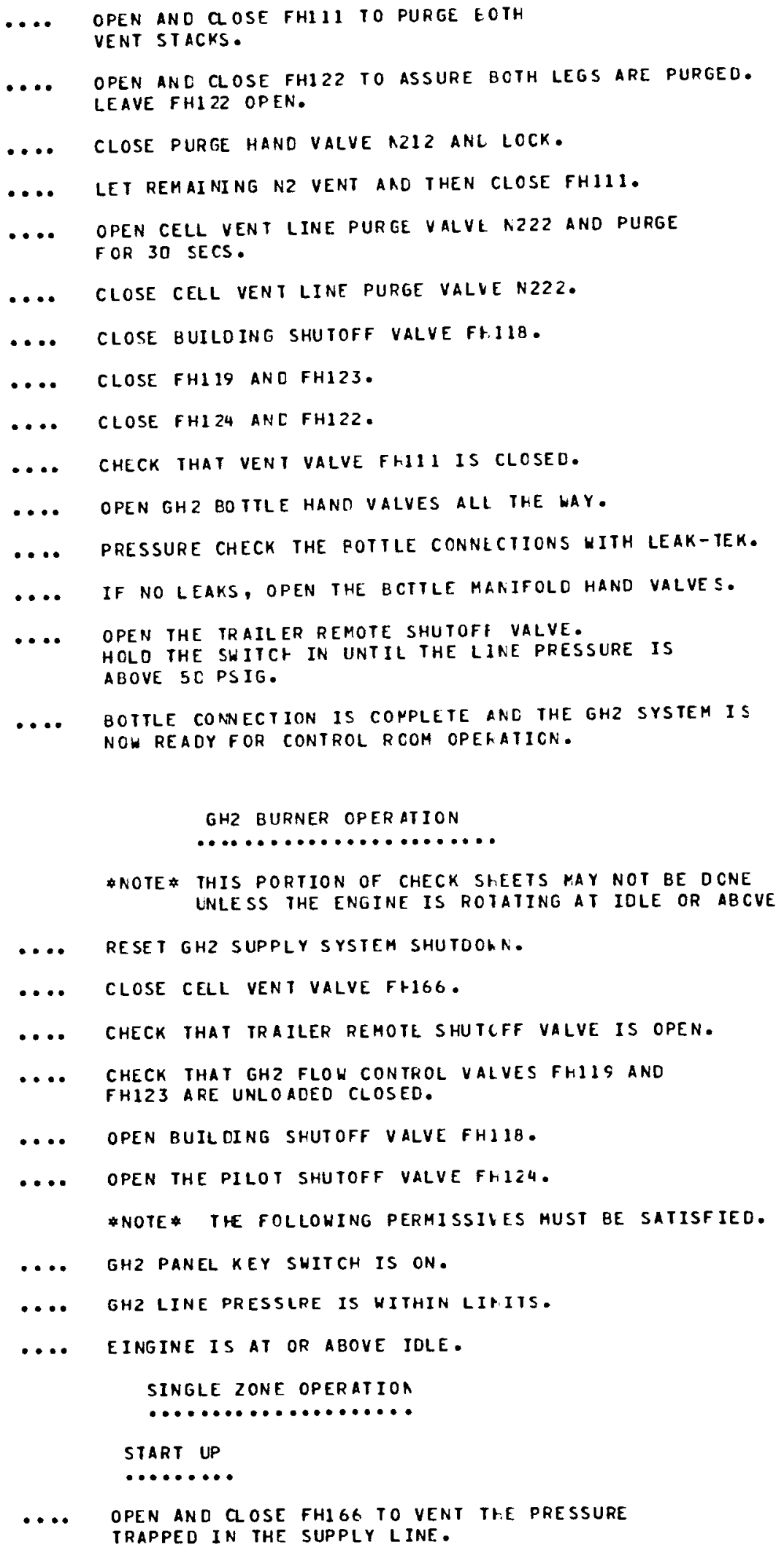




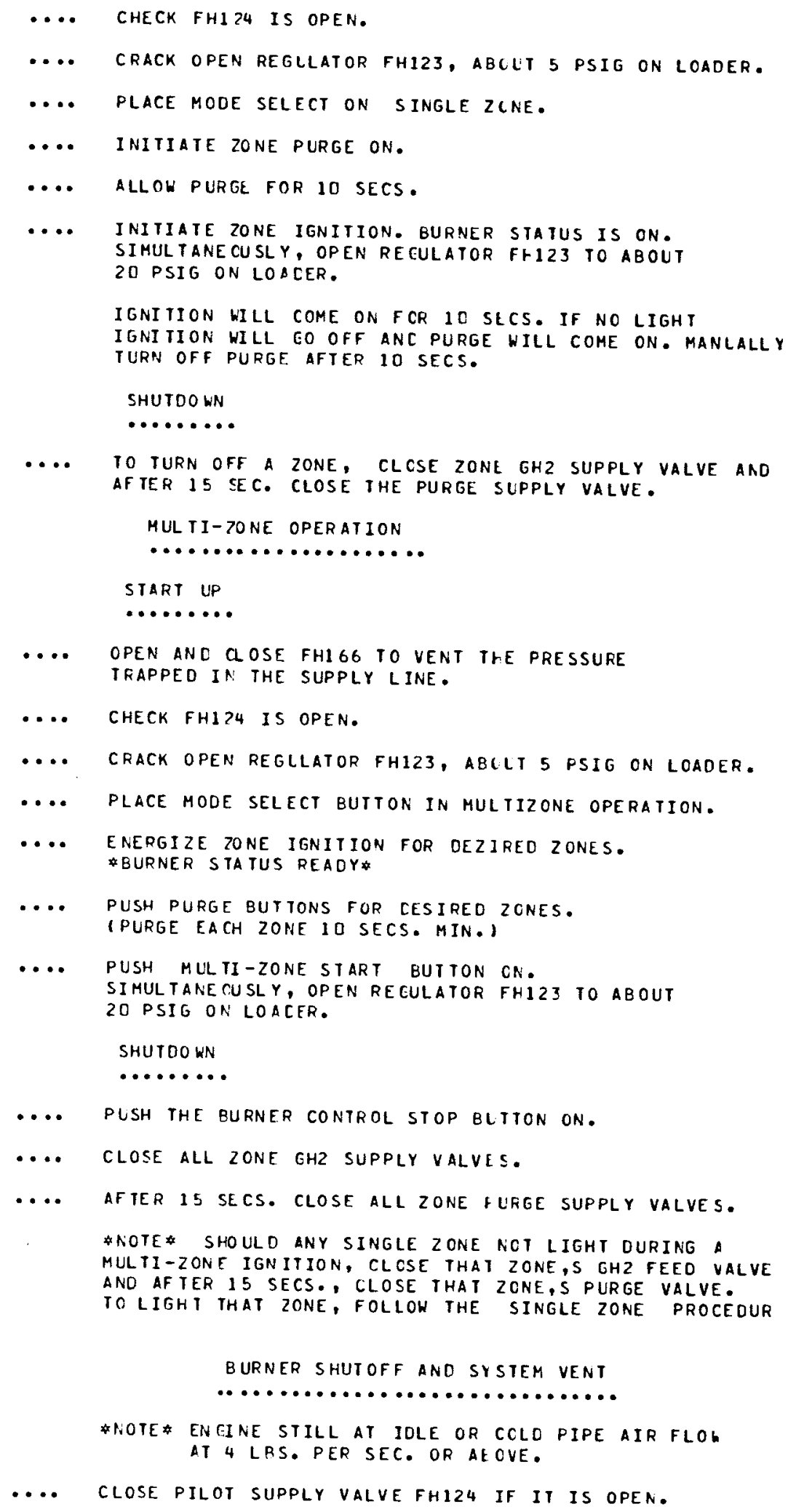


TABLE II. - Continued

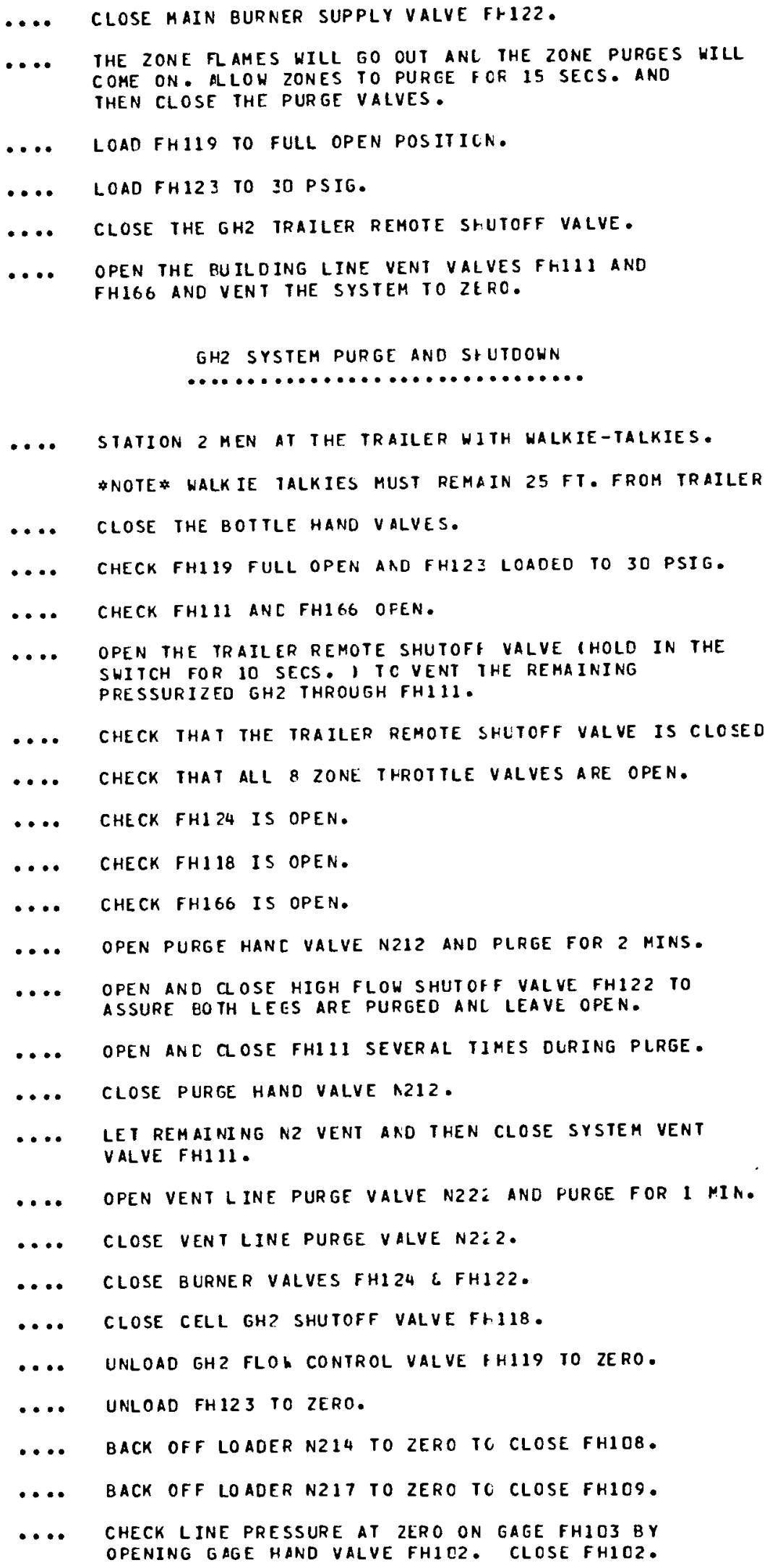


TABLE II. - Concluded

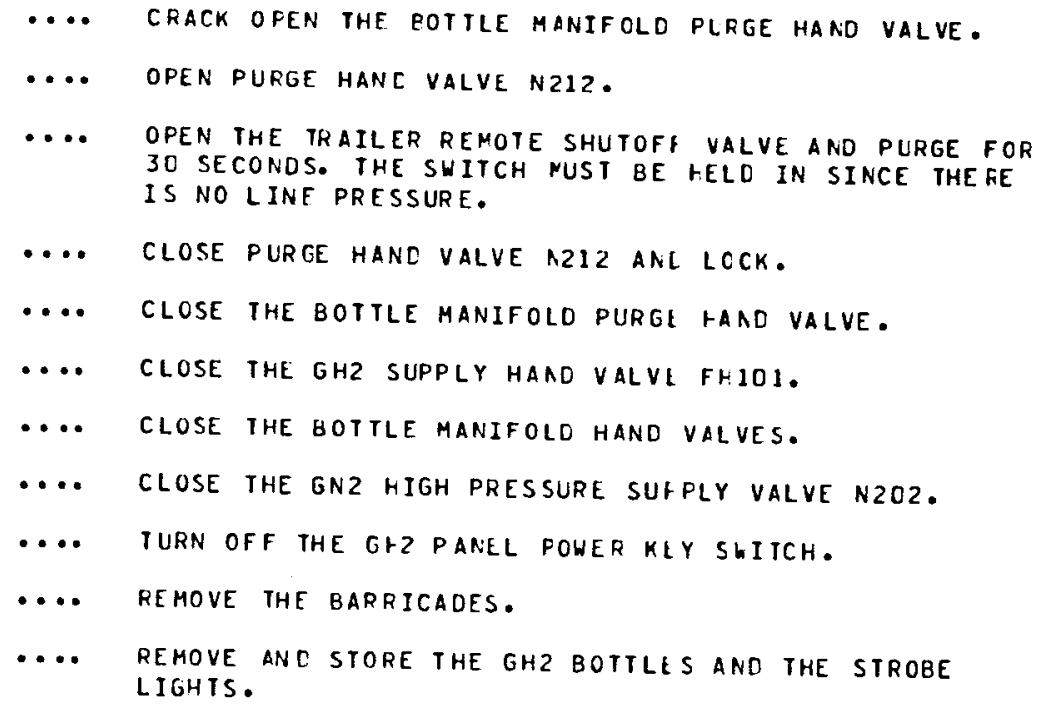


TABLE III - - HARDWARE

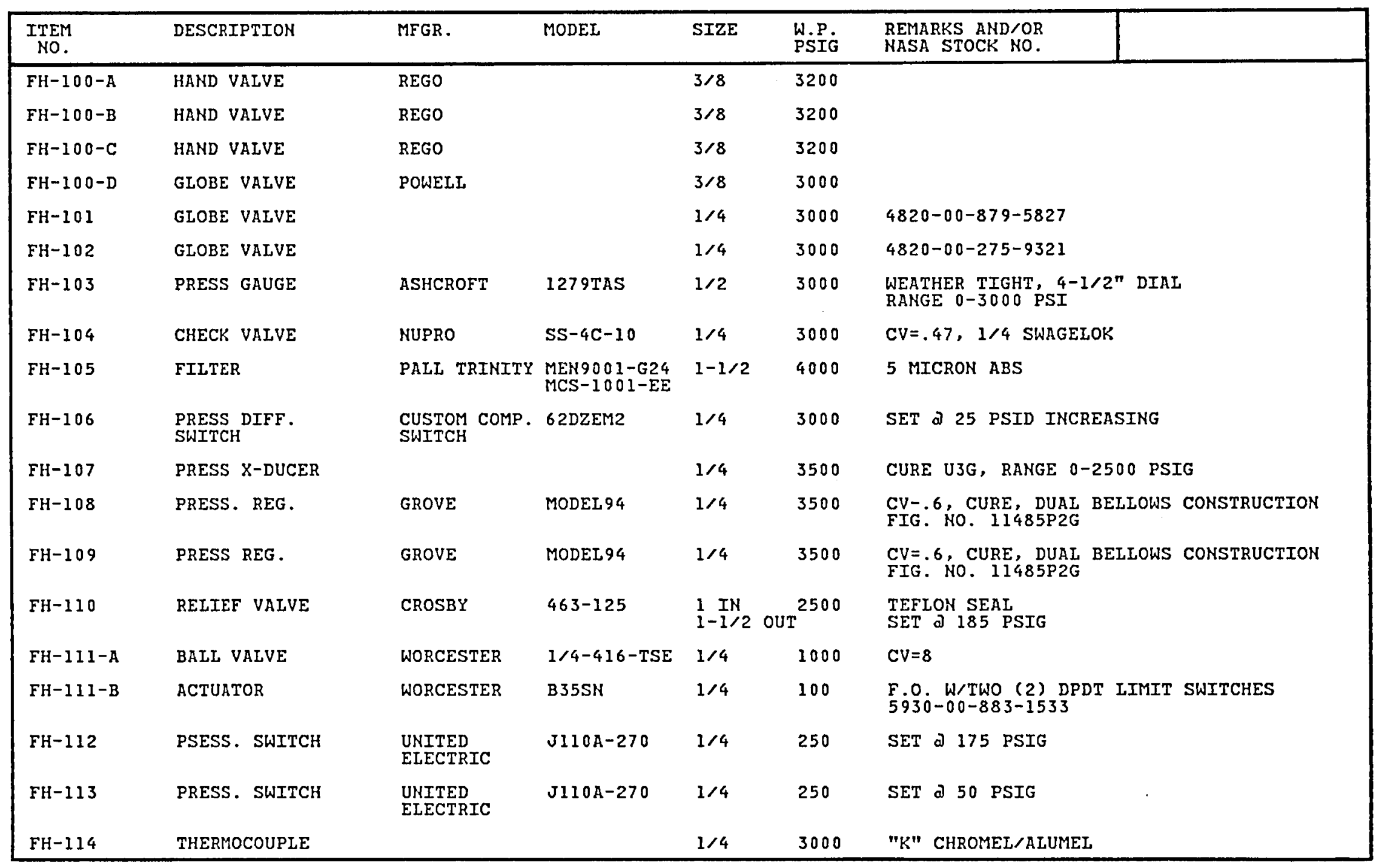


TABLE III. - Continued

\begin{tabular}{|c|c|c|c|c|c|c|}
\hline $\begin{array}{l}\text { ITEM } \\
\text { NO. }\end{array}$ & DESCRIPTION & MFGR. & MODEL. & SIZE & $\begin{array}{l}\text { W.P. } \\
\text { PSIG }\end{array}$ & $\begin{array}{l}\text { REMARKS AND/OR } \\
\text { NASA STOCK NO. }\end{array}$ \\
\hline FH-115 & PRESS. $X$-DUCER & & & $1 / 4$ & 2500 & CURE U3G, RANGE $0-200$ PSIA \\
\hline $\mathrm{FH}-116$ & VENTURI & FLOW DYNE & V080200 & $1 / 2$ & 500 & $\begin{array}{l}\text { THROAT DIA. }=.200 \text { IN. S.S. BODY } \\
1 / 8 " 37 \text { DEG. TUBE FITTINGS ON THROAT POR }\end{array}$ \\
\hline $\mathrm{FH}-117$ & $\begin{array}{l}\text { PRESS. DIFF. } \\
X-D U C E R\end{array}$ & & & $1 / 4$ & 2000 & $\begin{array}{l}\text { CURE U4E } \\
\text { RANGE } 0-25 \text { PSID }\end{array}$ \\
\hline FH-118-A & BALL VALVE & WORCESTER & $1 / 2-416-T S E$ & $1 / 2$ & 1000 & \\
\hline$F H-118-B$ & ACTUATOR & WORCESTER & B38SN & $1 / 4$ & 100 & $\begin{array}{l}\text { F.O. W/TWO (2) DPDT LIMIT } \\
\text { SWITCHES } \\
5930-00-883-1533\end{array}$ \\
\hline $\mathrm{FH}-119$ & GLOBE VALVE & ANNIN & 1660 & $1 / 2$ & 1200 & $C V=1.0$ PERCENTAGE; CURE \\
\hline$F H-122-A$ & BALL VALVE & WORCESTER & $1 / 2-416-T S E$ & $1 / 2$ & 1000 & $\mathrm{CV}=8.0$ \\
\hline $\mathrm{FH}-122-\mathrm{B}$ & ACTUATOR & WORCESTER & $\mathrm{B} 38 \mathrm{SN}$ & $1 / 4$ & 100 & $\begin{array}{l}\text { F.C. W/TWO (2) DPDT IIMIT } \\
\text { SWITCHES } \\
5930-00-883-1533\end{array}$ \\
\hline $\mathrm{FH}-123$ & GLOBE VALVE & & & $1 / 4$ & 3000 & $4820-00-554-9967$ \\
\hline $\mathrm{FH}-124$ & SCLENIOD VA. & ATKOMATIC & 15400 & $1 / 4$ & 300 & $C V=1.4$ \\
\hline $\mathrm{FH}-125$ & GLOBE VALVE & HOKE & $2355 F 4 Y$ & $1 / 4$ & 3000 & $\begin{array}{l}C V=.30 \\
\text { IIOTOR OPER.; OPER \# OI21F2E }\end{array}$ \\
\hline$F H-126$ & GLOBE VALVE & HOKE & $2355 F 4 Y$ & $1 / 4$ & 3000 & $\begin{array}{l}C V=.30 \\
\text { MOTOR OPER.; OPER \# O121F2E }\end{array}$ \\
\hline $\mathrm{FH}-127$ & GLOBE VALVE & HOKE & $2355 F 4 Y$ & $1 / 4$ & 3000 & $\begin{array}{l}\mathrm{CV}=.30 \\
\text { MOTOR OPER.; OPER \# O121F2E }\end{array}$ \\
\hline FH- 128 & GLOBE VALVE & HOKE & $2355 F 4 Y$ & $1 / 4$ & 3000 & $\begin{array}{l}\mathrm{CV}=.30 \\
\text { MOTOR OPER.; OPER \# OI2IF } 2 E\end{array}$ \\
\hline $\mathrm{FH}-129$ & GLOBE VALVE & HOKE & $2355 F 4 Y$ & $1 / 4$ & 3000 & $\begin{array}{l}C V=.30 \\
\text { MOTOR OPER.; OPER \# O12IF2E }\end{array}$ \\
\hline $\mathrm{FH}-130$ & GLOBE VALVE & HOKE & $2355 F 4 Y$ & $1 / 4$ & 3000 & $\begin{array}{l}C V=.30 \\
\text { MOTOR OPER.; OPER \# 0121F2E }\end{array}$ \\
\hline $\mathrm{FH}-131$ & GLOBE VALVE & HOKE & $2355 F 4 Y$ & $1 / 4$ & 3000 & $\begin{array}{l}C V=.30 \\
\text { MOTOR OPER.; OPER \# O121F2E }\end{array}$ \\
\hline $\mathrm{FH}-132$ & GLOBE VALVE & HOKE & $2355 F 4 Y$ & $1 / 4$ & 3000 & $\begin{array}{l}\mathrm{CV}=.30 \\
\text { MOTOR OPER.; OPER \# 012IF2E }\end{array}$ \\
\hline $\mathrm{FH}-133$ & CHECK VALVE & NUPRO & $5 S-4 C-10$ & $1 / 4$ & 3000 & $C V=.47 ; 1 / 4 "$ SWAGELOK \\
\hline$F H-134$ & CHECK VALVE & NUPRO & $5 S-4 C-10$ & $1 / 4$ & 3000 & $C V=.47 ; 1 / 4 "$ SWAGELOK \\
\hline
\end{tabular}


TABLE III. - Continued

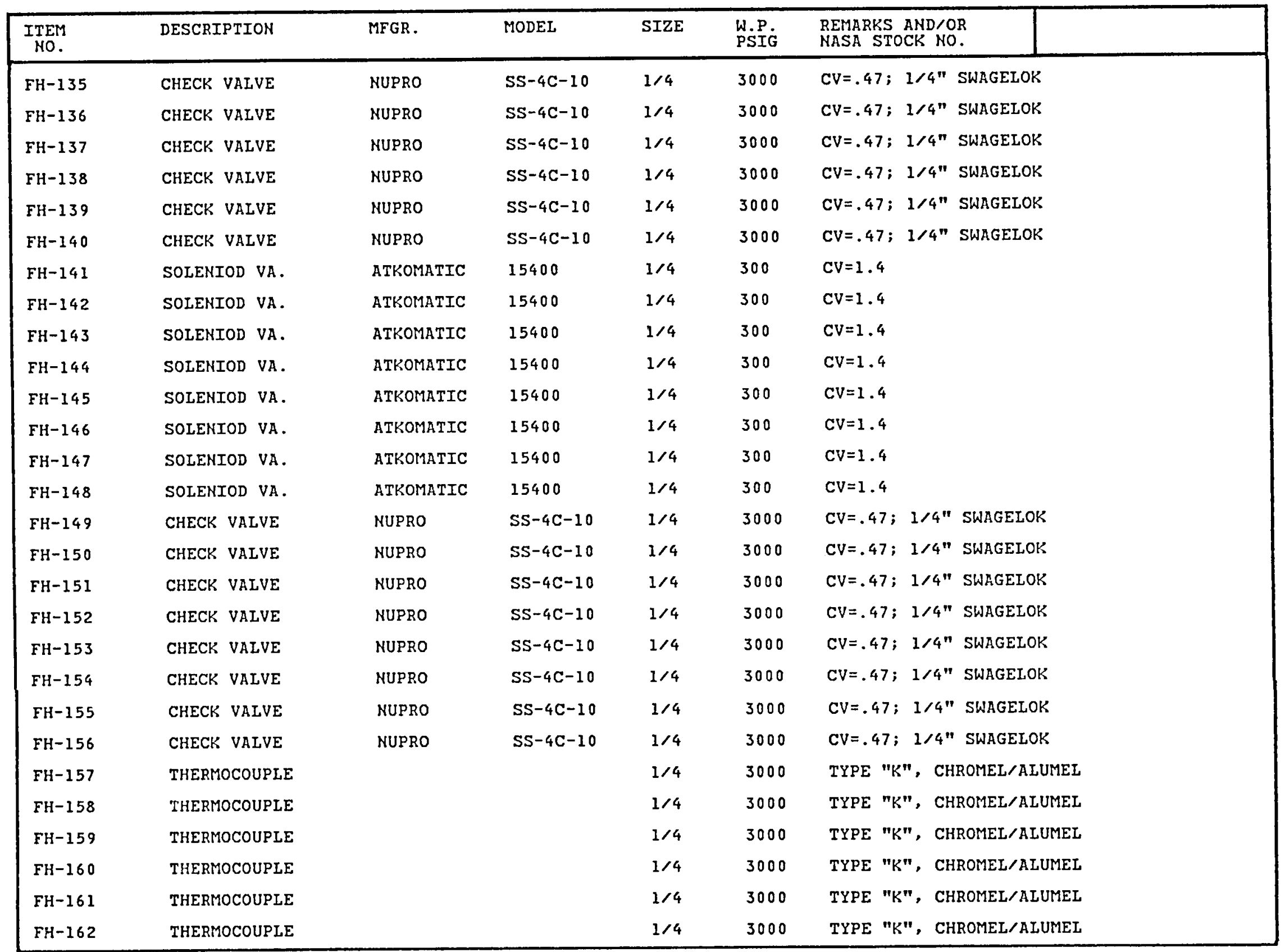


TABLE III - - Cont inued

\begin{tabular}{|c|c|c|c|c|c|c|}
\hline $\begin{array}{l}\text { ITEM } \\
\text { NO. }\end{array}$ & DESCRIPTION & MFGR. & MODEL & SIZE & $\begin{array}{l}\text { W.P. } \\
\text { PSIG }\end{array}$ & $\begin{array}{l}\text { REMARKS AND/OR } \\
\text { NASA STOCK NO. }\end{array}$ \\
\hline $\mathrm{FH}-163$ & THERMOCOUPLE & & & $1 / 4$ & 3000 & TYPE "K", CHROMEL/ALUMEI \\
\hline$F H-164$ & THERMOCOUPIE & & & $1 / 4$ & 3000 & TYPE "K", CHROMEL/ALUMEL \\
\hline FH- 165 & CHECK VALVE & NUPRO & $S S-4 C-10$ & $1 / 4$ & 3000 & CV-.47; 1/4" SWAGELOK \\
\hline $\mathrm{FH}-166-\mathrm{A}$ & BALL VALVE & WORCESTER & $1 / 2-416-T S E$ & $1 / 4$ & 1000 & $\mathrm{CV}-8.0$ \\
\hline $\mathrm{FH}-166-\mathrm{B}$ & ACTUATOR & WORCESTER & B38SN & $1 / 4$ & 100 & $\begin{array}{l}\text { W/TWO (2) DPDT LIMIT SWITCHES } \\
5930-00-883-1533\end{array}$ \\
\hline FH- 167 & CHECK VALVE & REPUBLIC & $483-1-B-1$ & 1 & 3000 & $\mathrm{CV}=.3 ; \mathrm{CURE}$ \\
\hline FH-168-A & GAUGE & U.S. GAUGE & & $1 / 4$ & 500 & RANGE $0-500$ PSIG \\
\hline $\mathrm{FH}-168-\mathrm{B}$ & GLOBE VALVE & HOKE & R380AK & $1 / 4$ & & \\
\hline$F H-169-\AA$ & GAUGE & U.S. GAUGE & & $1 / 4$ & 500 & RANGE $0-500$ PSIG \\
\hline$F H-169-B$ & GLOBE VALVE & HOKE & R380AK & $1 / 4$ & & \\
\hline$N-201$ & PRESS X-DUCER & & & $1 / 4$ & 3000 & CURE U3G; RANGE $0-2500$ PSIG \\
\hline$N-202$ & GLOBE VALVE & & & $1 / 4$ & 3000 & $4820-00-879-5827$ \\
\hline$N-203$ & CYLINDER REG. & HARRIS CAL. & $92-100-580$ & & 4000 & $\begin{array}{l}\text { CURE; INLET CGA-580 } \\
\text { INLET } 9 / 16-18 \mathrm{RH}\end{array}$ \\
\hline$N-204$ & RELIEF VALVE & $\begin{array}{l}\text { REPUBLIC } \\
3 / 8-M 6\end{array}$ & $8-2366$ & $3 / 8$ & 3000 & CURE; SET a 75 PSIG \\
\hline$N-205$ & SOLENIOD VA. & ASCO & $8320-A 185$ & $1 / 4$ & 150 & $\mathrm{CV}=.15$ \\
\hline $\mathrm{N}-206$ & FLEXHOSE & & & & & NASA ASSY \\
\hline$N-208$ & PRESS. SWITCH & $\begin{array}{l}\text { UNITED } \\
\text { ELECTRIC }\end{array}$ & J302-610 & $1 / 4$ & 10,000 & $\begin{array}{l}\text { SETA } 200 \text { PSIG, DECREASING } \\
\text { RANGE } 100-1000 \text { PSIG }\end{array}$ \\
\hline$N-209$ & CYLINDER REG. & $\begin{array}{l}\text { HARRIS } \\
\text { CAIORIFIC }\end{array}$ & $93-250-580$ & & 4000 & $\begin{array}{l}\text { CURE; SET a } 150 \text { PSIG } \\
\text { RANGE } 0-250 \text { PSIG }\end{array}$ \\
\hline$N-210$ & RELIEF VALVE & REPUBLIC & $\begin{array}{l}637 \mathrm{~B}-3- \\
3 / 4-\mathrm{TU} 5\end{array}$ & $3 / 4$ & 3000 & CURE; SET a 175 PSIG \\
\hline$N-211$ & CHECK VALVE & & & 1 & 3000 & $\mathrm{CV}-13 ; 4820-00-529-4384$ \\
\hline $\mathrm{N}-212$ & BALL VALVE & JAMESBURY & $1 / 2-B 36 G T$ & $1 / 2$ & 3000 & CV-8.0 W/LOCKING HANDLE \\
\hline$N-213$ & CYLINDER REG. & $\begin{array}{l}\text { HARRIS } \\
\text { CALORIFIC }\end{array}$ & $93-350-580$ & & 4000 & $\begin{array}{l}\text { CURE; INLET CGA580 } \\
\text { OUTLET } 9 / 16-18 \mathrm{RH}\end{array}$ \\
\hline$N-214$ & LOADER & TESCOM & $26-1623-24$ & $1 / 4$ & 6000 & $\begin{array}{l}\text { CURE; CV }=08 \text { RELIEVING } \\
\text { RANGE } 0-500 \text { PSI }\end{array}$ \\
\hline
\end{tabular}


TABLE III. - Continued

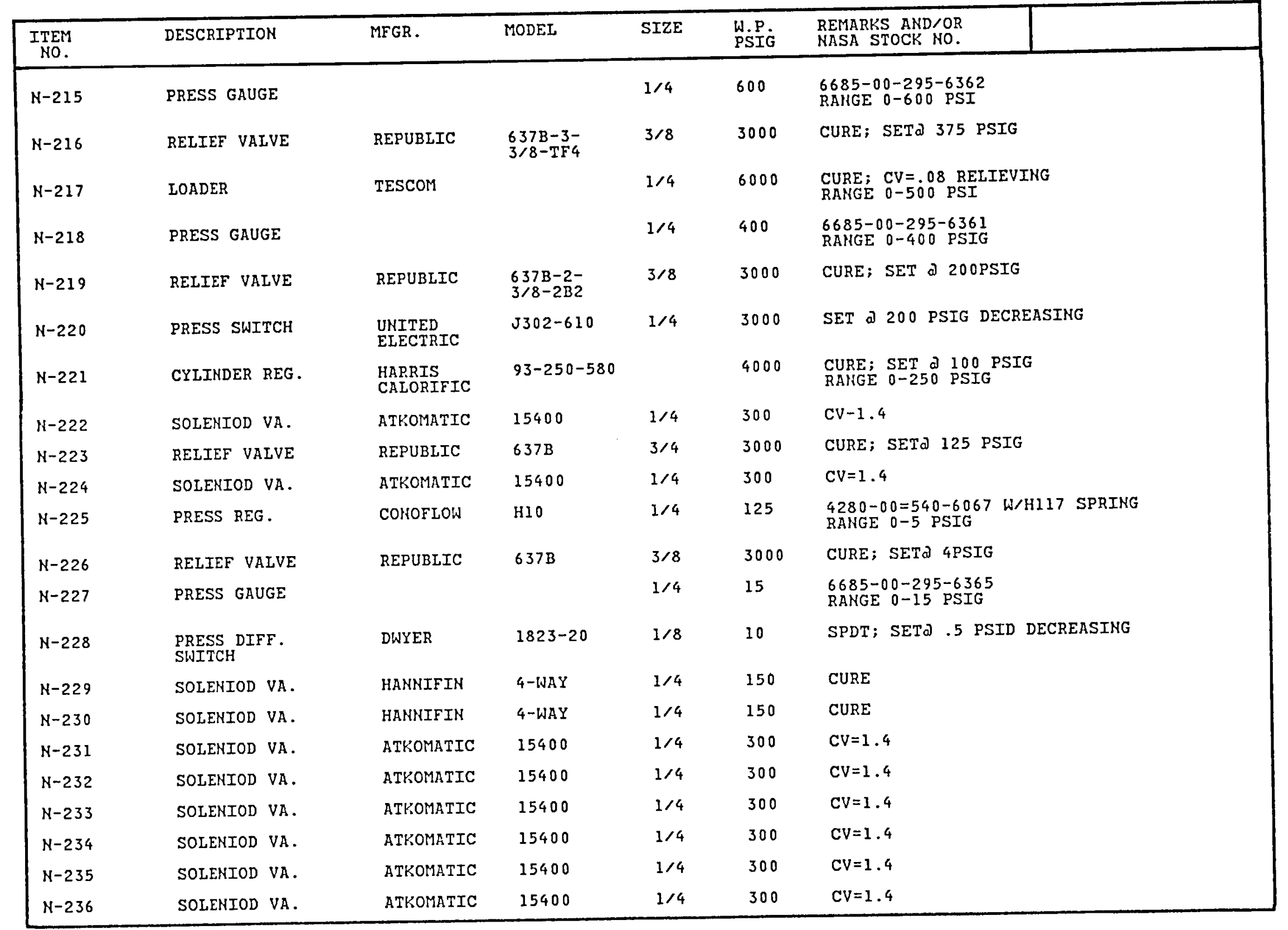


TABLE III - - Concluded

\begin{tabular}{|c|c|c|c|c|c|c|}
\hline $\begin{array}{l}\text { ITEI1 } \\
\text { NO. }\end{array}$ & DESCRIPTION & MFGR. & MODEL & SIZE & $\begin{array}{l}\text { W.P. } \\
\text { PSIG }\end{array}$ & $\begin{array}{l}\text { REMARKS AND/OR } \\
\text { NASA STOCK NO. }\end{array}$ \\
\hline$N-237$ & SOLERIOD VA. & ATKOMATIC & 15400 & $1 / 4$ & 300 & $C V=1.4$ \\
\hline$N-238$ & SOLENIOD VA. & ATKOMATIC & 15400 & $1 / 4$ & 300 & $C V=1.4$ \\
\hline$A I-301$ & LOADER & & & $1 / 4$ & 150 & $\begin{array}{l}4820-00-540-6067 \\
\text { RANGE } 0-15 \text { PSIG }\end{array}$ \\
\hline$A I-302$ & PRESS GAUGE & & & $1 / 4$ & 30 & $\begin{array}{l}6685-00-295-6354 \\
\text { RANGE } 0-30 \text { PSIG }\end{array}$ \\
\hline AS -402 & SOLENOID VA. & HANHIFIN & 4-WAY & $1 / 4$ & 150 & CURE \\
\hline AS -403 & SOLENOID VA. & HANRIFIN & 4-WAY & $1 / 4$ & 150 & CURE \\
\hline
\end{tabular}


TABLE IV. - TIME CONSTANT CALIBRATION RESULTS

[Stream static pressure, $p, 14.41$ psia.]

\begin{tabular}{|c|c|c|c|}
\hline $\begin{array}{c}\text { Stream } \\
\text { Mach } \\
\text { number }\end{array}$ & $\begin{array}{c}\text { Probe } \\
\text { indicated } \\
\text { temperature, } \\
T_{1}, \\
{ }^{\circ}\end{array}$ & $\begin{array}{c}\text { Measured } \\
\text { time } \\
\text { constant, } \\
\tau, \\
\text { sec }\end{array}$ & $\begin{array}{c}\text { Reference } \\
\text { time } \\
\text { constant, } \\
\text { To } \\
\text { sec }\end{array}$ \\
\hline 0.40 & 160 & 0.222 & 0.127 \\
.30 & 147 & .253 & .126 \\
.20 & 156 & .300 & .122 \\
.15 & 160 & .365 & .128 \\
.10 & 156 & .490 & .141 \\
0 & 170 & 1.05 & 0 \\
\hline
\end{tabular}




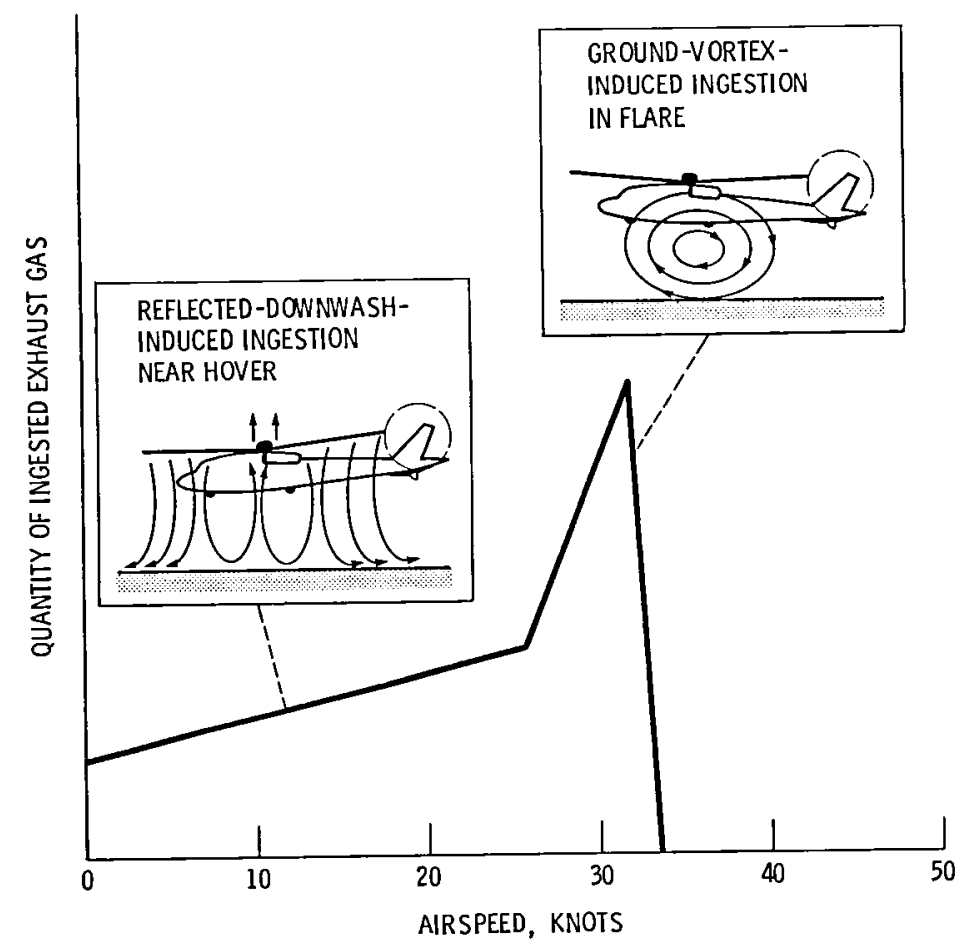

Figure 1. - Patterns of exhaust ingestions near ground.

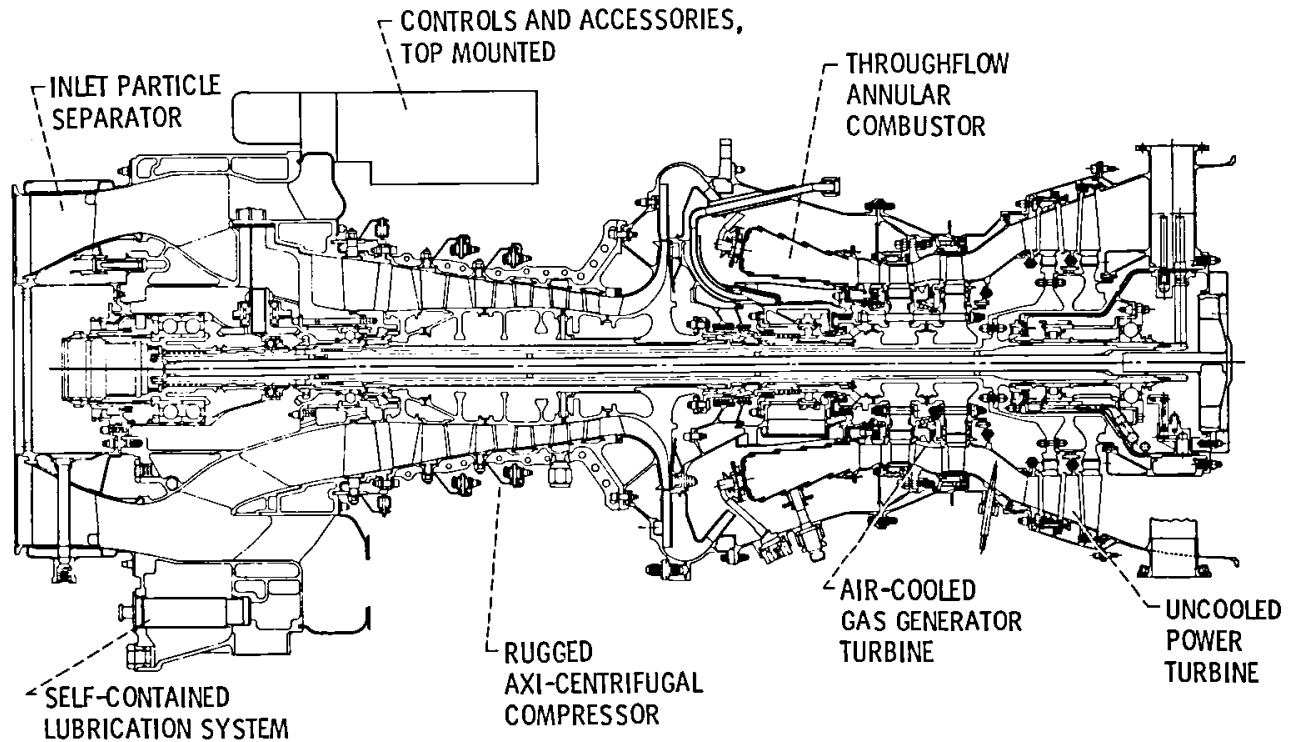

Figure 2 - Schematic of T700 engine. 


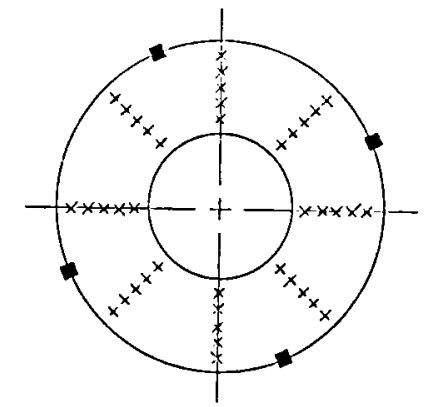

STATION I - ENGINE INLET

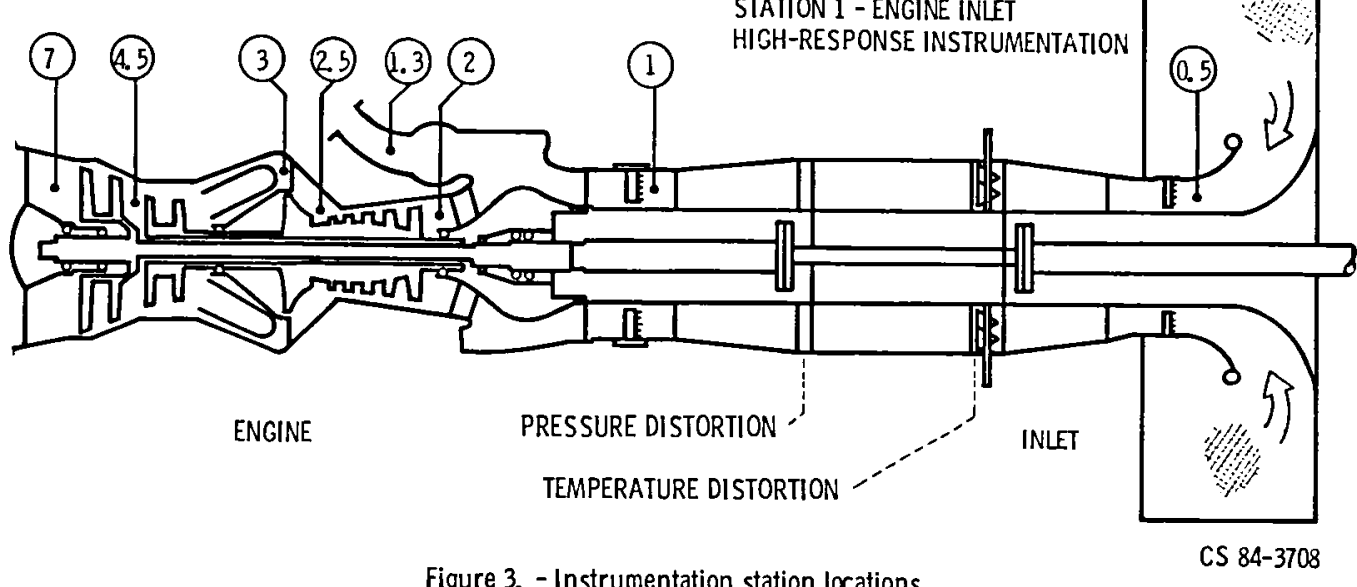

Figure 3. - Instrumentation station locations. 


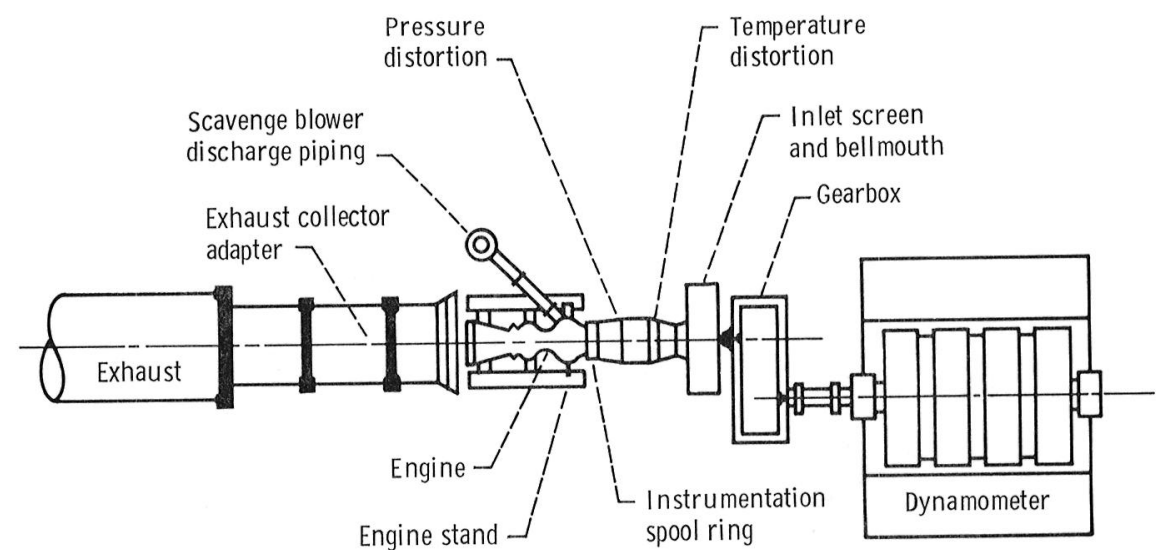

(a) Plan view (not to scale).

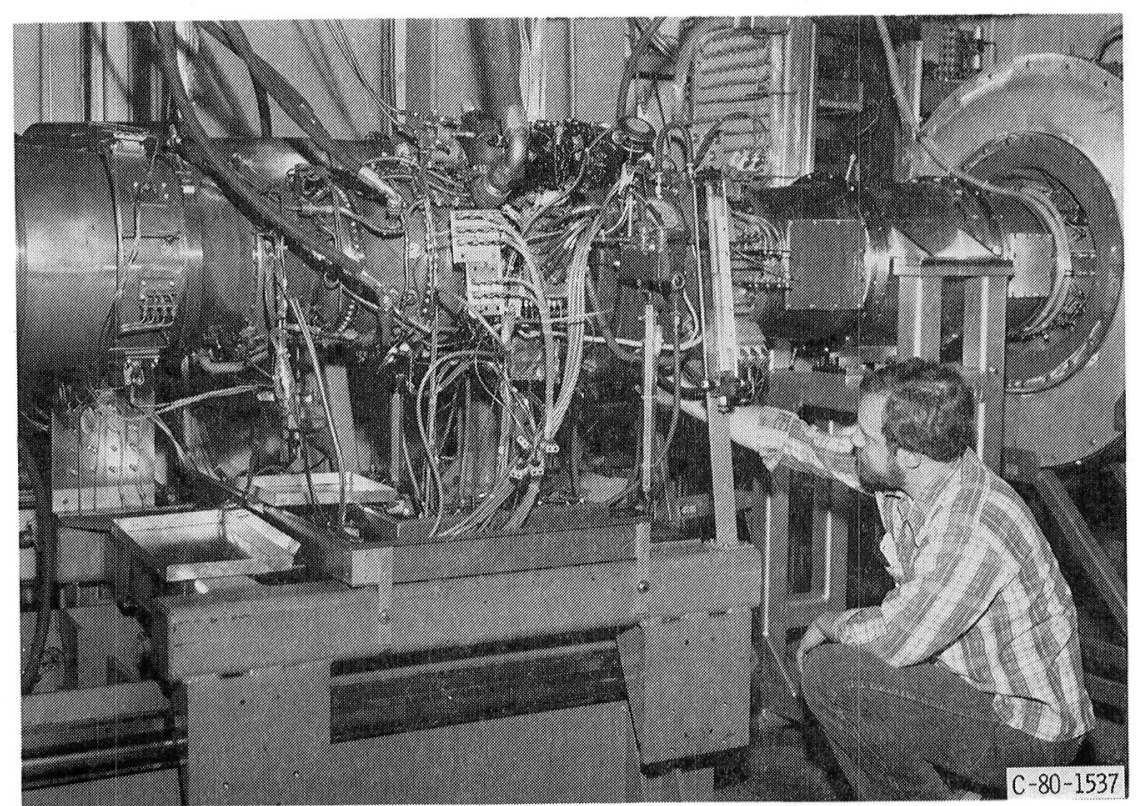

(b) Engine installation.

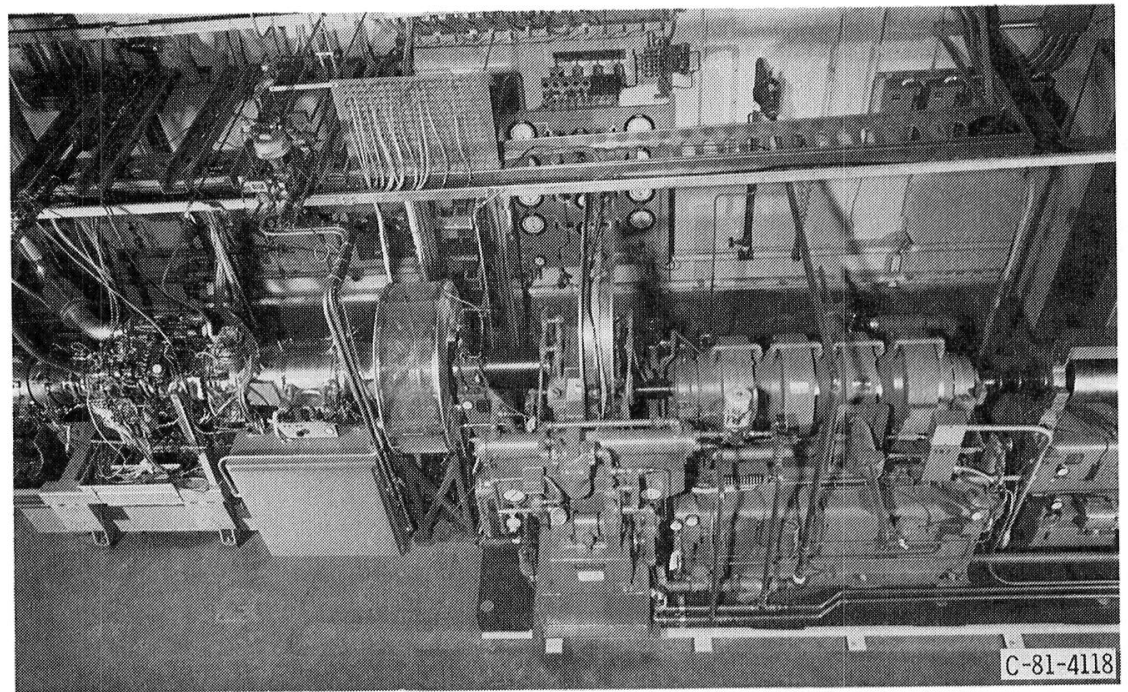

(c) Test cell overview.

Figure 4. - Test cell. 


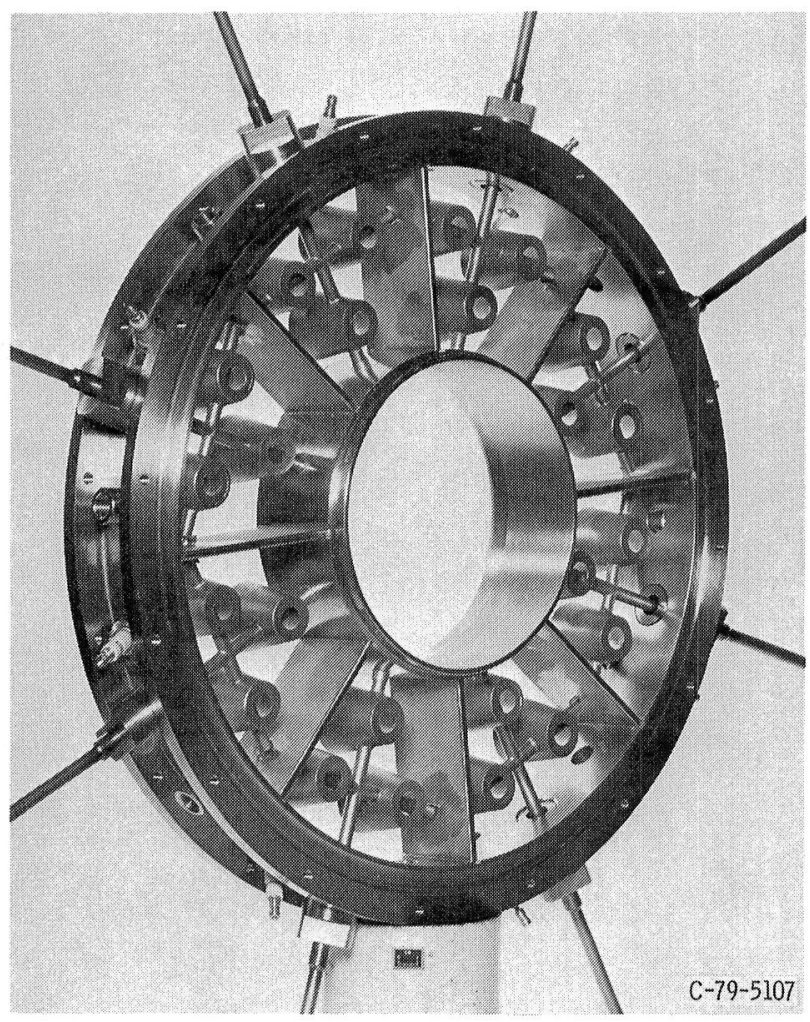

(a) Looking downstream.

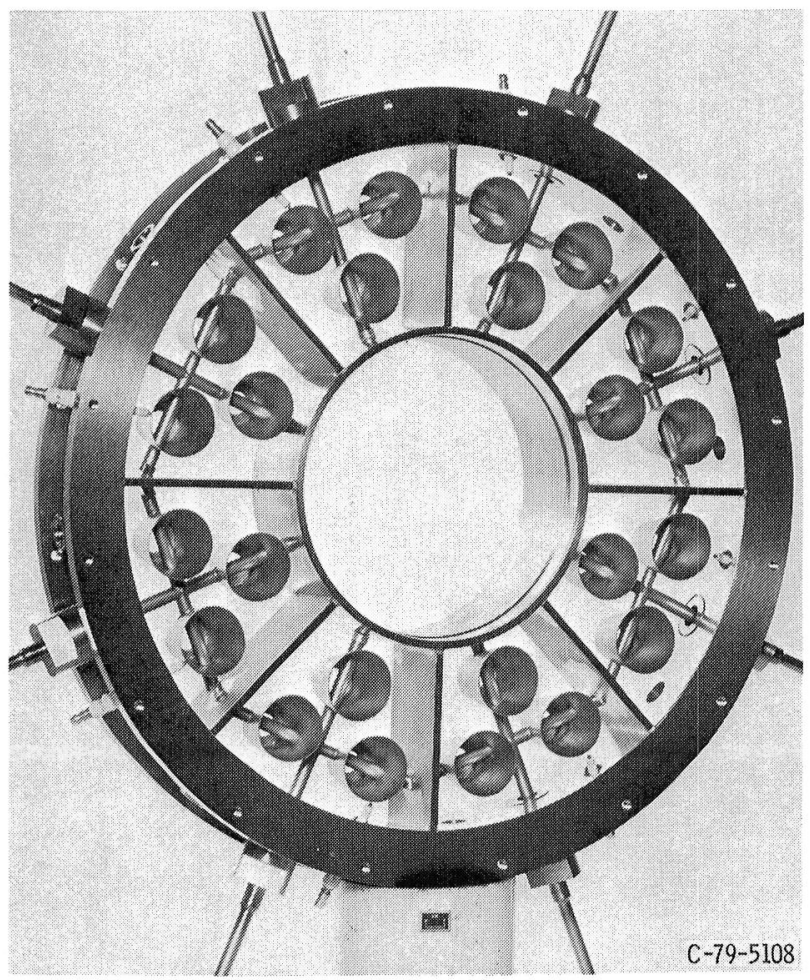

(b) Looking upstream.

Figure 5. - Temperature distortion generator. 


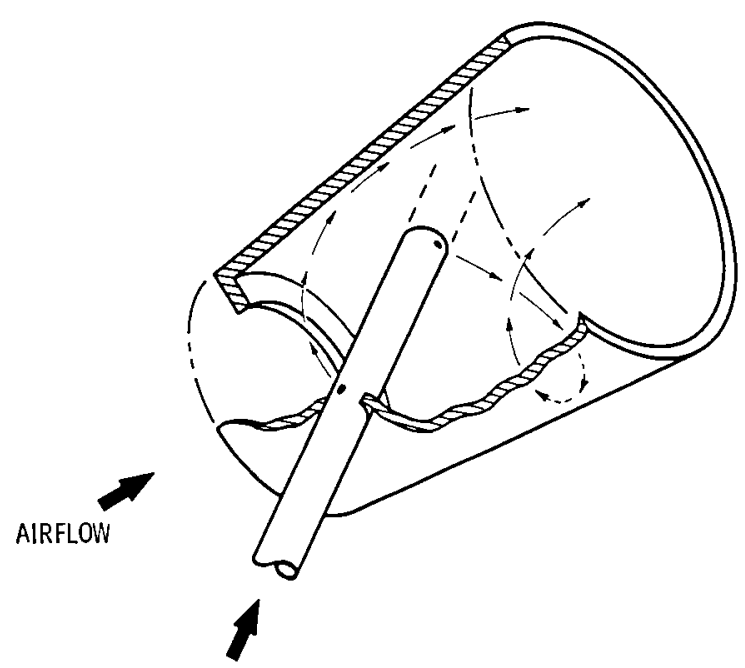

FUEL (GASEOUS HYDROGEN)

Figure 6. - Operation of typical swirl-cup combustor. 


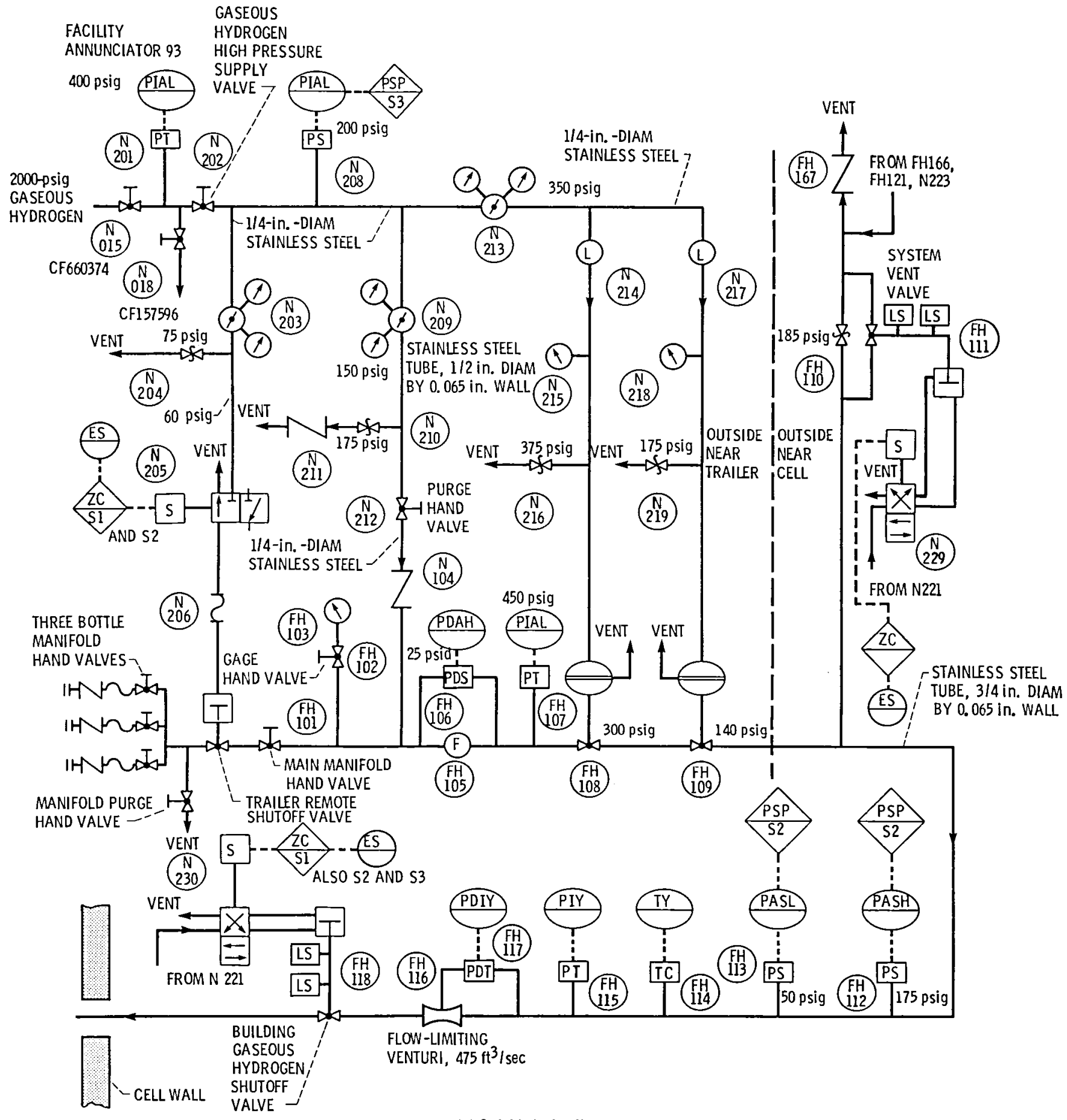

(a) Outside test cell.

Figure 7. - Distortion generator gaseous hydrogen supply system. 


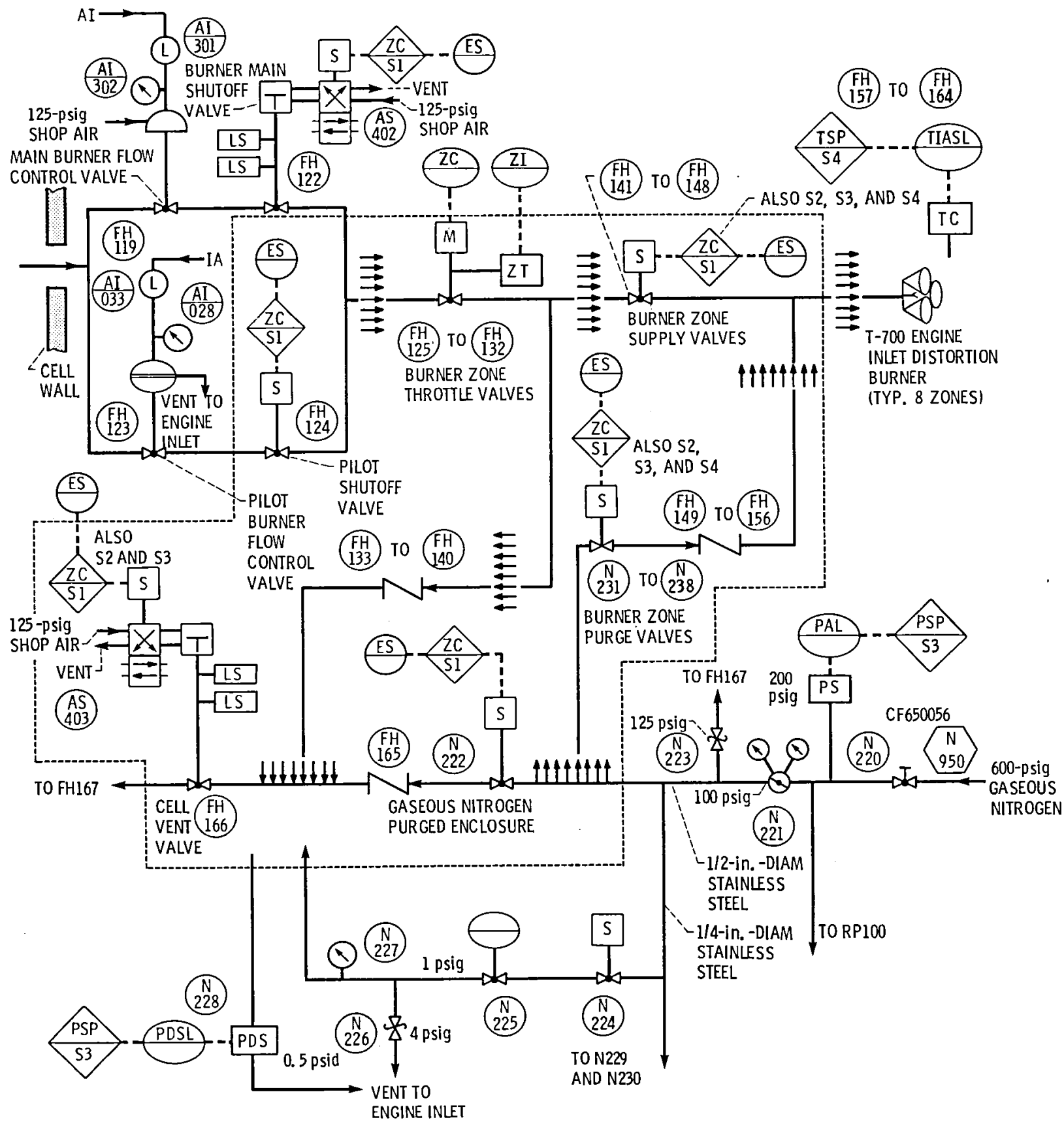

(b) In side test cell.

Figure 7. - Continued. 


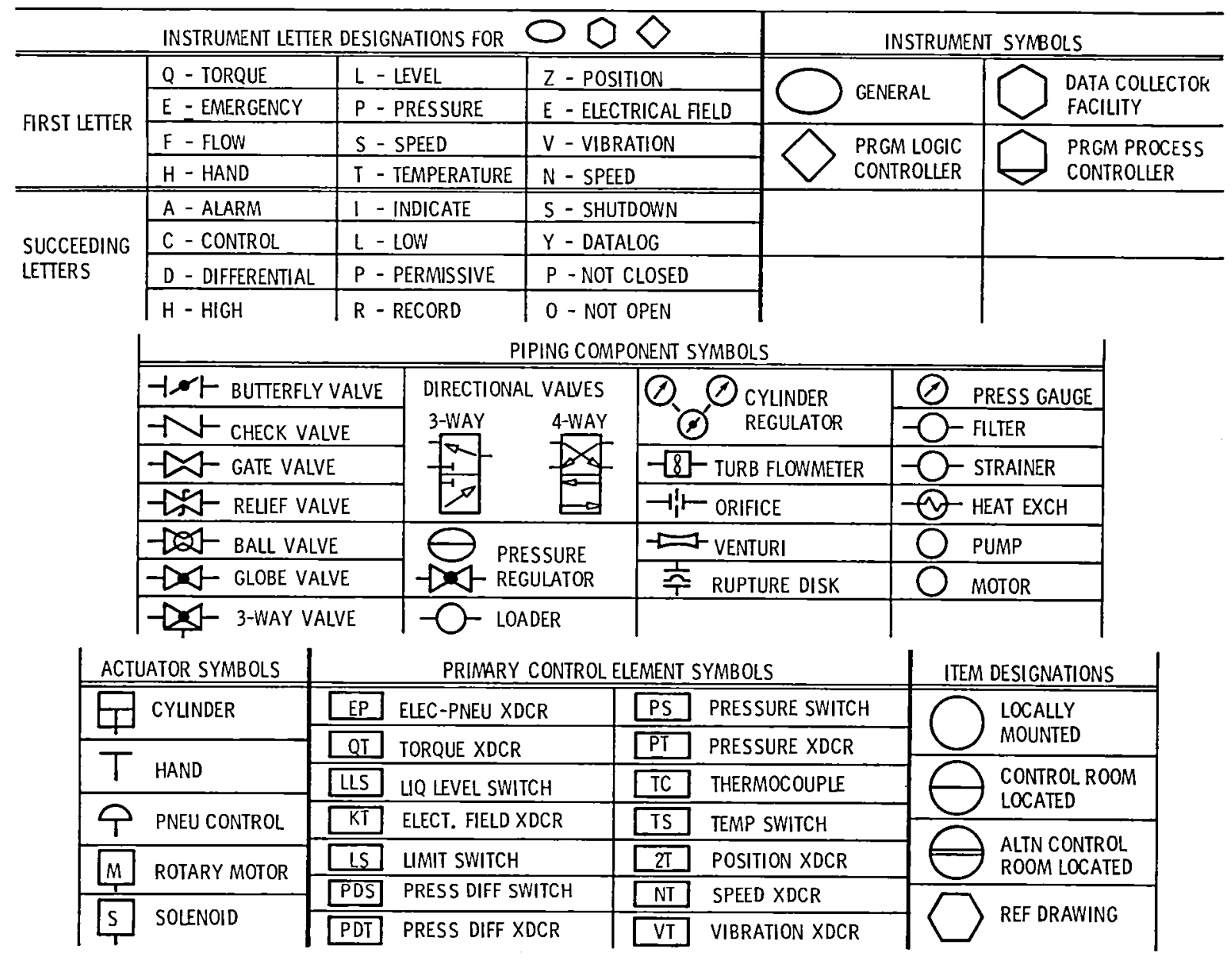

(c) Legend.

Figure 7. - Concluded. 


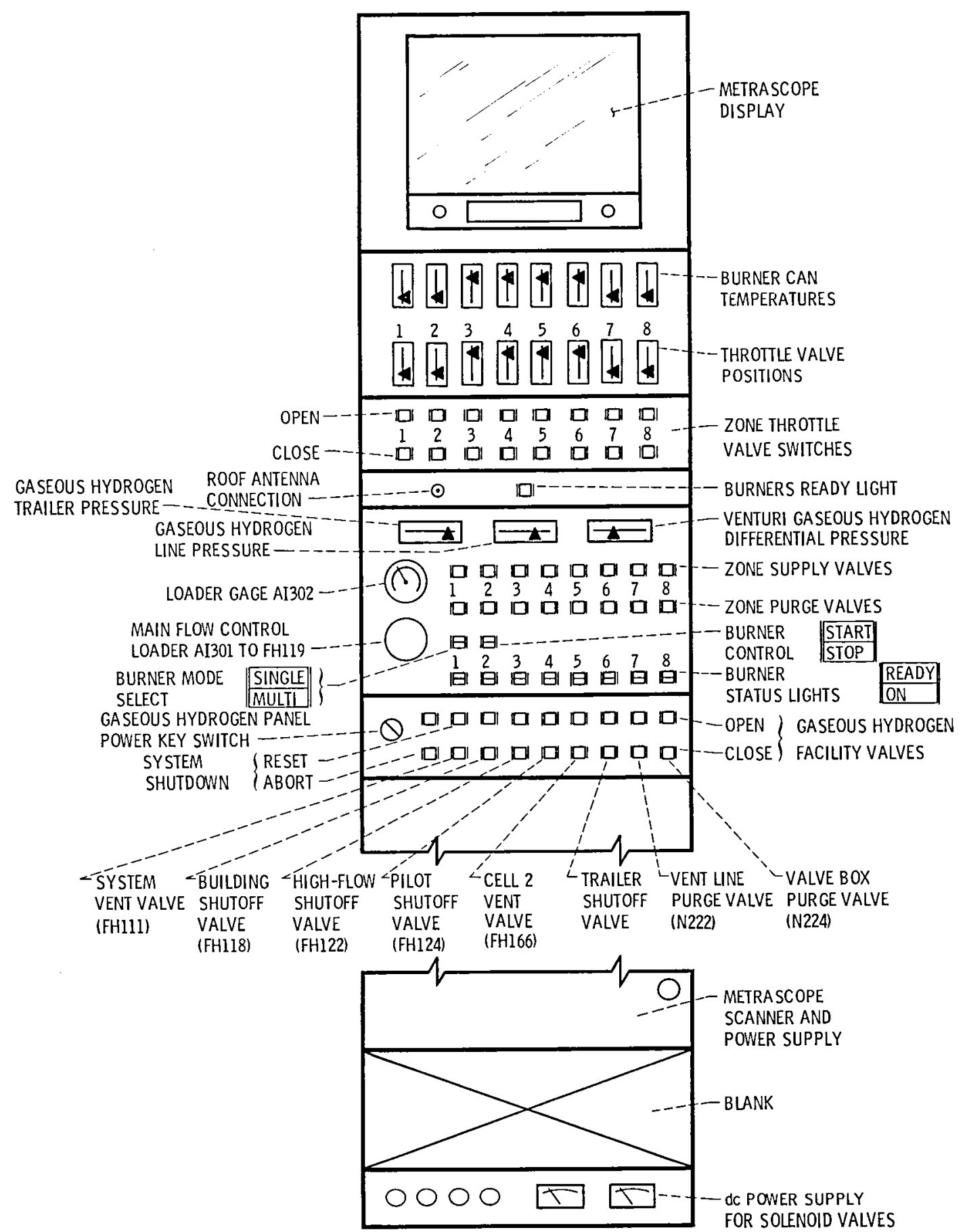

Figure 8. - Hydrogen system control panel. Pilot flow control loader AI033 to FH123 and gage AIO28 are in cabinet 13. 

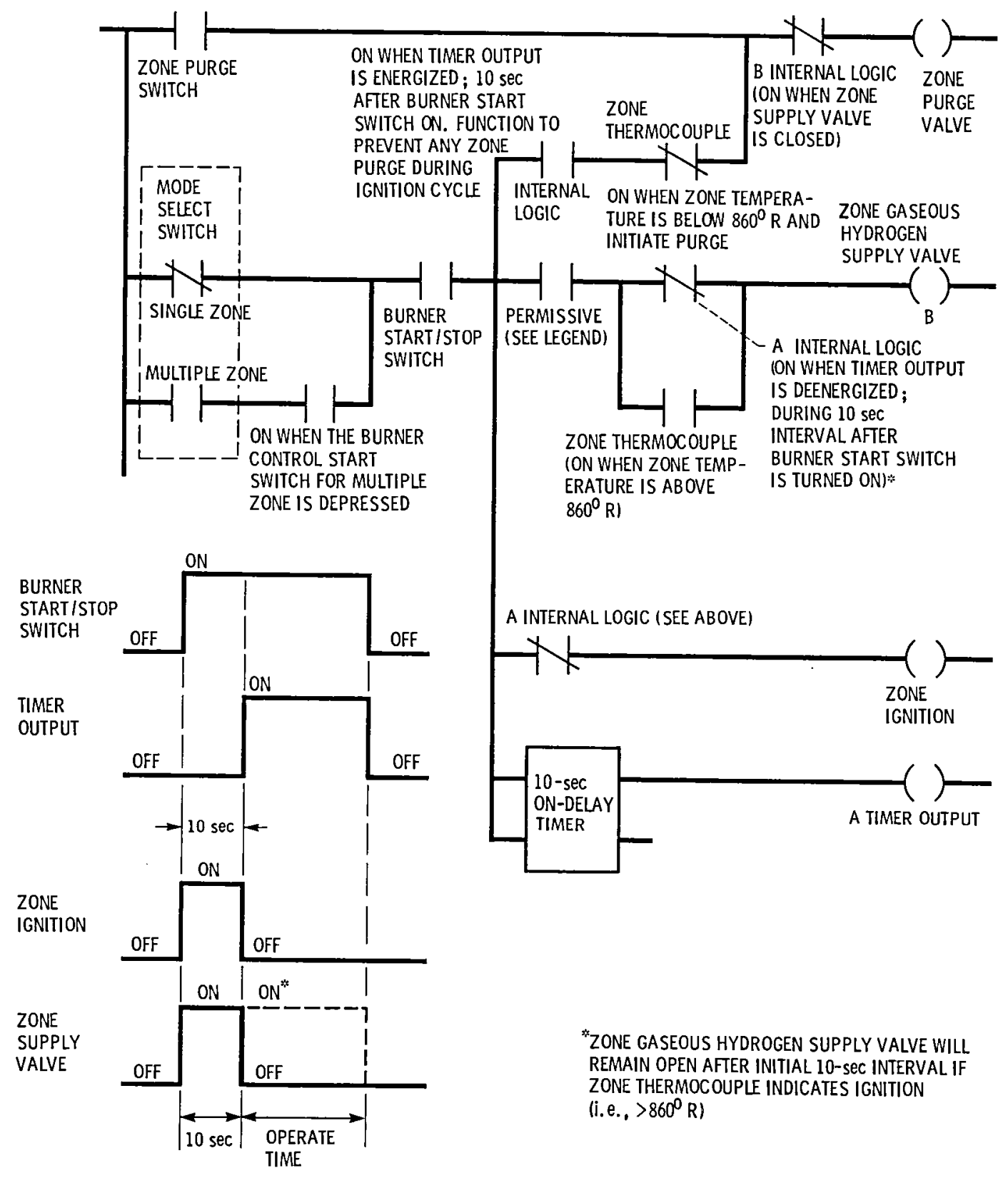

Figure 9. - Control logic for hydrogen system burner zones. Permissive is satisfied when (1) system on/off panel switch is on; (2) system reset switch is depressed; (3) engine is at or above idle speed; (4) valve box purge pressure is $>0.5$ psid; (5) gaseous hydrogen line pressure is $>50 \mathrm{psig}$; (6) burner gaseous nitrogen purge pressure is $>200 \mathrm{psig}$; (7) gaseous hydrogen line pressure is < 175 psig; (8) facility gaseous nitrogen purge pressure is > $400 \mathrm{psig}$; and (9) gaseous hydrogen key switch is on. 


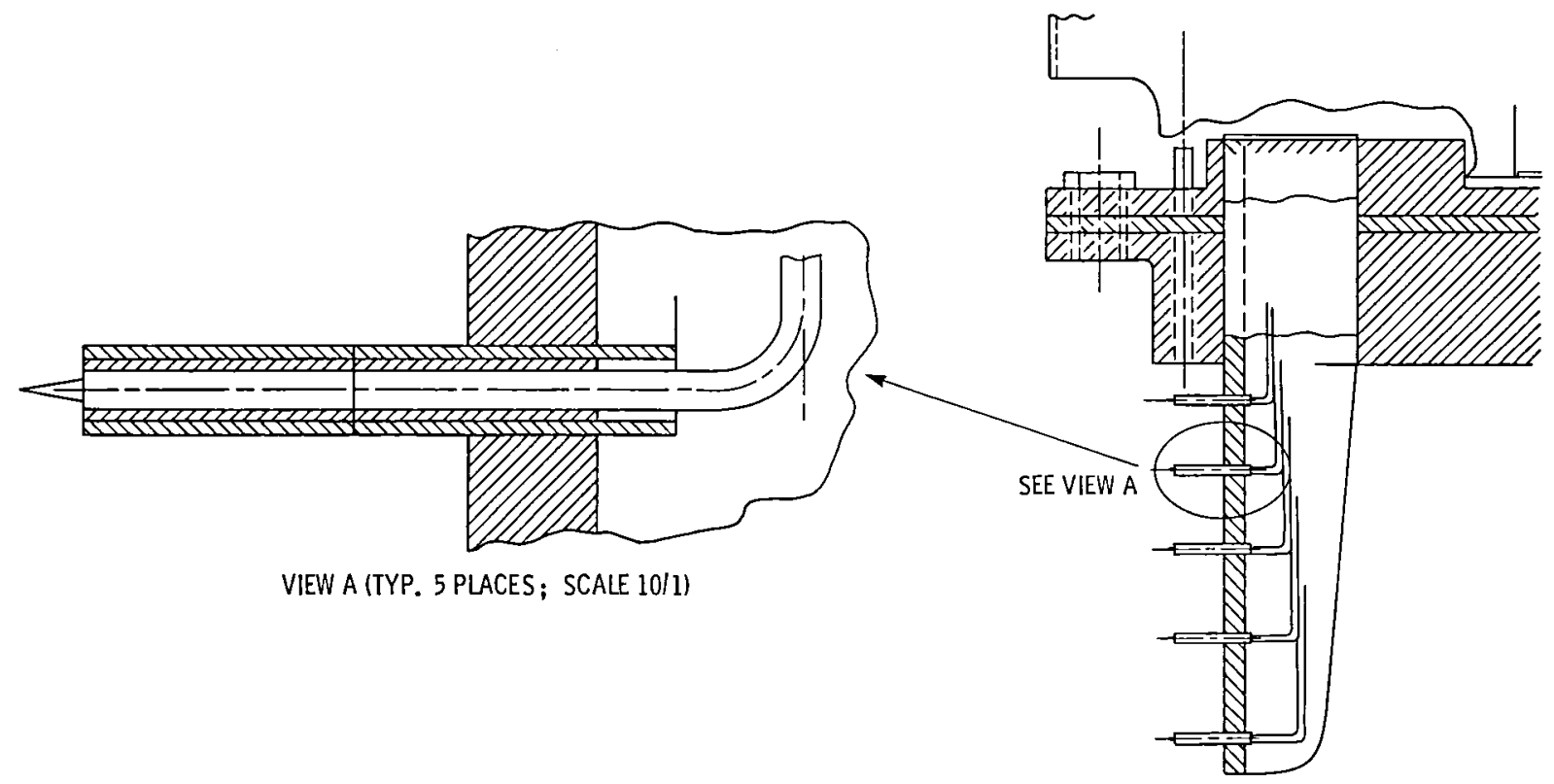

Figure 10, - Chromel-Alumel thermocouple probe.

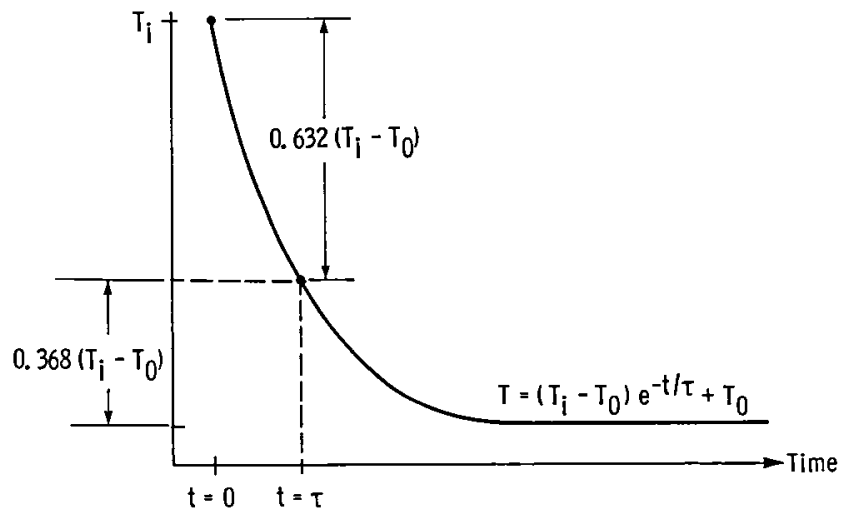

Figure 11. - Exponential decay curve. 


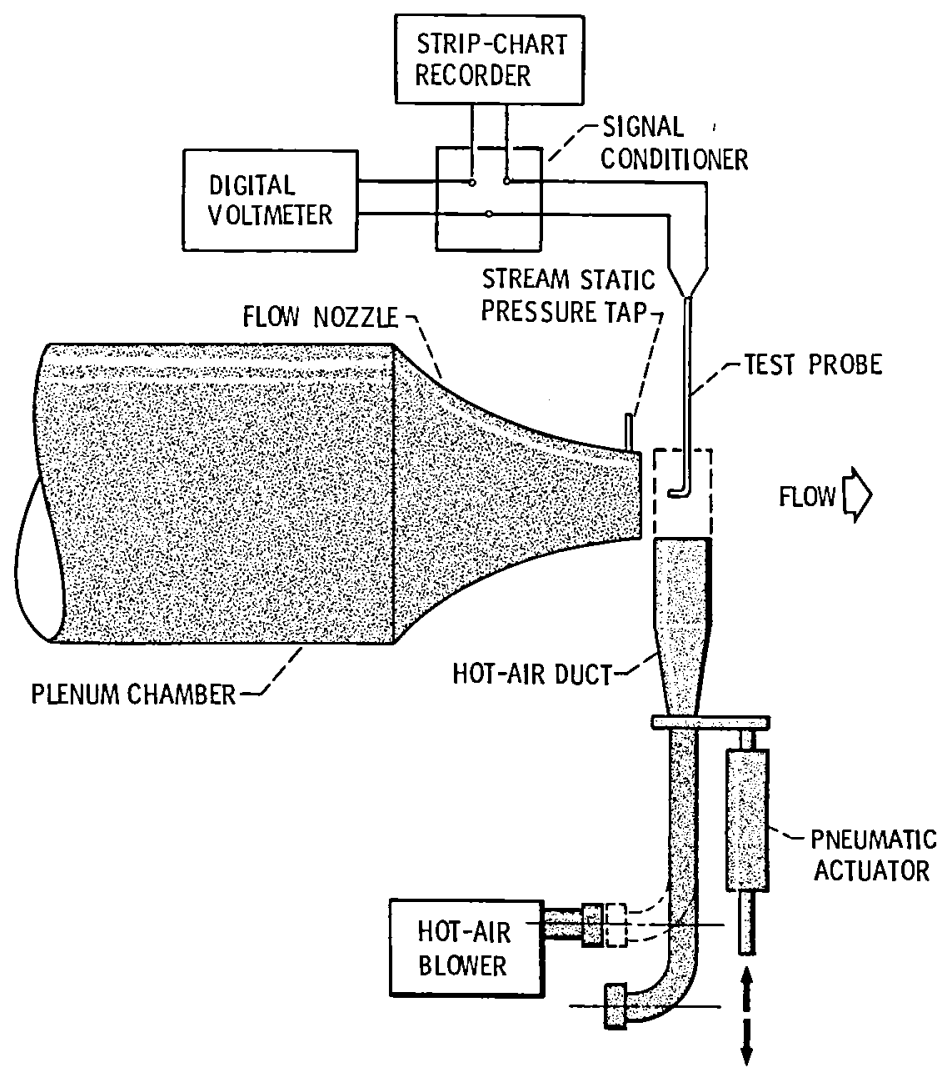

Figure 12. - Time-constant test apparatus.

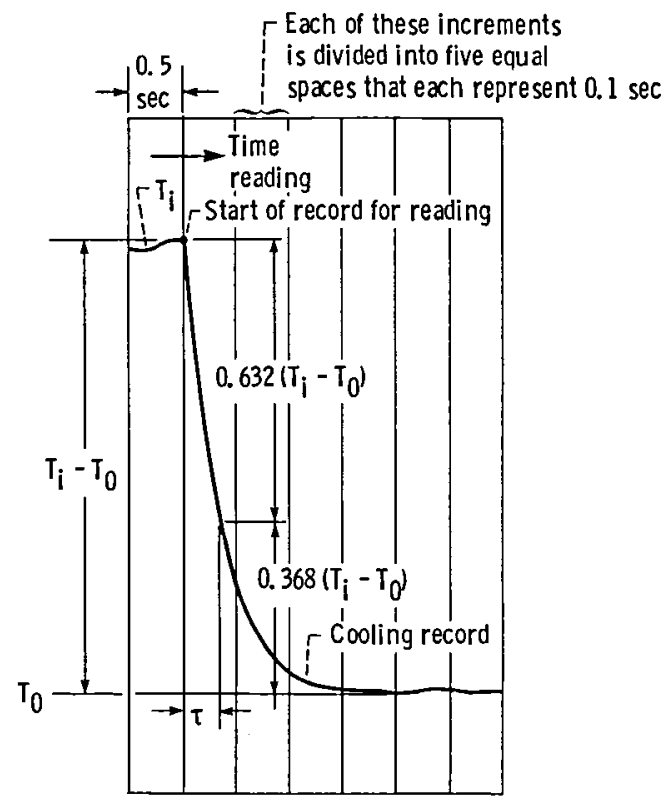

Figure 13. - Sample record. 



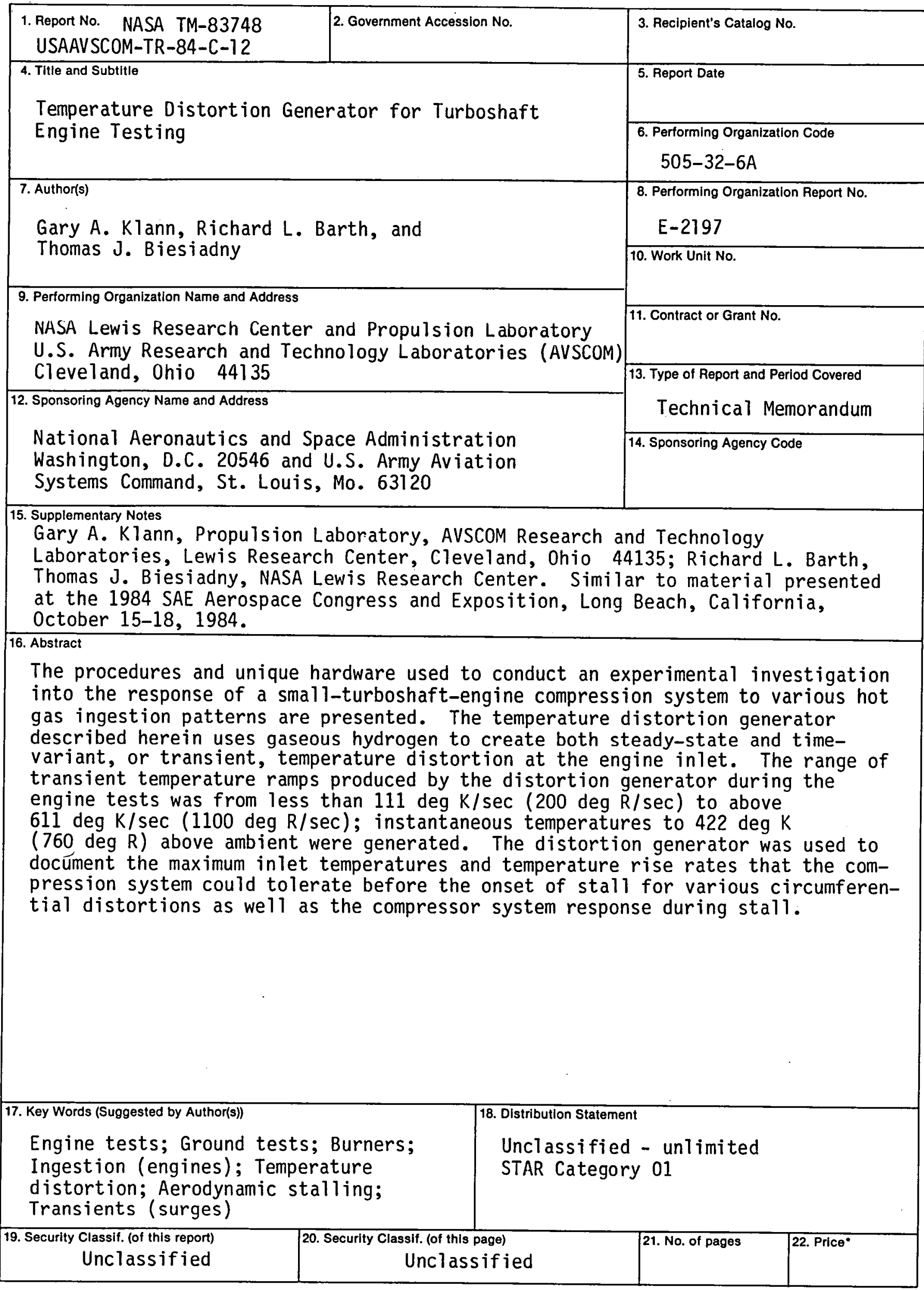


National Aeronautics and Space Administration

Washington, D.C.

20546

Official Business

Penaliy for Private Use, $\mathbf{5 3 0 0}$
SPECIAL FOURTH CLASS MAIL BOOK

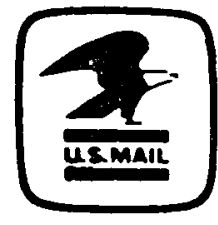

Postage and Fees Paid National Aeronautics and Space Administration NASA-451 